NBER WORKING PAPER SERIES

MOBILE POLITICIANS:

OPPORTUNISTIC CAREER MOVES AND MORAL HAZARD

Duha T. Altindag

Naci Mocan

Working Paper 21438

http://www.nber.org/papers/w21438

\author{
NATIONAL BUREAU OF ECONOMIC RESEARCH \\ 1050 Massachusetts Avenue \\ Cambridge, MA 02138 \\ July 2015
}

We thank Brian Jacob, Madeline Mocan, Briggs Depew, Özkan Eren, Gilad Sorek, Jonathan Klick, Bryan McCannon, Tim Willems, Paolo Roberti, Marco Vannini, Claudio Detotto and seminar participants at the 6th Workshop on Institutions, Individual Behavior and Economic Outcomes in Alghero, Sardinia; University of Wisconsin at La Crosse, and Auburn University for helpful comments, and Uğur Saçı and Ülkü Altındağ for their help in data collection The views expressed herein are those of the authors and do not necessarily reflect the views of the National Bureau of Economic Research.

NBER working papers are circulated for discussion and comment purposes. They have not been peerreviewed or been subject to the review by the NBER Board of Directors that accompanies official NBER publications.

(C) 2015 by Duha T. Altindag and Naci Mocan. All rights reserved. Short sections of text, not to exceed two paragraphs, may be quoted without explicit permission provided that full credit, including $\odot$ notice, is given to the source. 
Mobile Politicians: Opportunistic Career Moves and Moral Hazard

Duha T. Altindag and Naci Mocan

NBER Working Paper No. 21438

July 2015

JEL No. D72,K0

\begin{abstract}
$\underline{\text { ABSTRACT }}$
We exploit the randomness generated by a seat allocation mechanism utilized in Parliamentary elections that determines those politicians who get elected from a given district by a small margin, and those who lose. Using detailed information on personal attributes of more than 2,000 elected Members of the Parliament (MPs) and the votes received by each political party in every district and each of the five consecutive Parliamentary elections in Turkey between 1991 and 2011, we show that elected MPs are more likely to switch parties after an election if they faced electoral uncertainty and experienced a narrowly-won victory. The tendency to switch parties goes up as it becomes more lucrative to hold the post of MP. The impact of election uncertainty on party-switching is greater for younger MPs, and for those who are less educated. The propensity to switch due to uncertainty is higher if the MP is a member of the governing party, but only if the seat is valuable (if the majority of the party in the Parliament is slim). Politicians switch parties after an election to improve their ex-ante re-election probability in the following election. Although switching parties during a legislative session (between elections) for personal career concerns creates moral hazard, we find that party-switching MPs are more likely to get elected in the next election. These results point to forward-looking opportunistic behavior of politicians regarding their strategy to win future elections, and they indicate that politicians switch parties primarily for career concerns and for financial benefits that are associated with longer tenure in the Parliament. The results also signify that competition between political parties continues after the election, in the form of gaining seats in the Parliament post- election by transferring elected representatives of competing parties. This constitutes another dimension of the political agency problem.
\end{abstract}

Duha T. Altindag

Auburn University

Department of Economics

0334 Haley Center

Auburn AL, 36849

altindag@auburn.edu

Naci Mocan

Department of Economics

Louisiana State University

3039 BEC

Baton Rouge, LA 70803-6306

and NBER

mocan@1su.edu

An online appendix is available at:

http://www.nber.org/data-appendix/w21438 


\section{Mobile Politicians: Opportunistic Career Moves and Moral Hazard}

\section{Introduction}

There are significant returns to serving as an elected member of the legislative branch of the government. For example, in the UK, being a member of the Parliament triples the probability that a Conservative Party member of the Parliament serves as a director of a publicly traded firm, and doubles the wealth of such members (Eggers and Hainmueller 2009). Dal Bó, Dal Bó and Snyder (2009) show that legislators who were successful in getting re-elected to the U.S. Congress are more likely to have their relatives entering Congress in the future, suggesting a self-perpetuating power structure. Fisman, Schulz and Vig (2013) and Bhavnani (2012) analyze Indian elections and find that assets of elected Indian politicians grow faster than the runners-up, suggesting that winning an election is associated with wealth accumulation. In addition to financial rewards, holding an elected office also provides non-pecuniary benefits such as the prestige and various perks of the office and the ability to impact public policy. ${ }^{1}$

An incumbent's goal of getting re-elected, however, does not always coincide with the interest of their constituents; and this creates a political agency problem. Politicians' desire to remain in office may generate moral hazard, because such desire could motivate them to make decisions and implement policies that may not be in the best interest of voters, although such actions may enhance politicians' re-election prospects. Based on this premise, a branch of political business cycle studies investigates the extent to which incumbents manipulate voters by higher spending and larger budget deficits in election years. (Drazen and Eslava 2010, Malley et

\footnotetext{
${ }^{1}$ Whether or not politicians stay in politics in reaction to these parameters has been analyzed theoretically and empirically (Keane and Merlo 2010, Besley 2004, Diermeier, Keane and Merlo 2005).
} 
al. 2007, Shi and Svensson 2006, Brender and Drazen 2005, Alesina, Roubini and Cohen 1997, Rogoff 1990).

In this paper we implement a different approach to test elected politicians' moral hazard. We have a direct measure of dishonest behavior of elected politicians, which undeniably conflicts with voter interests. As we explain in detail in the next section, we investigate politicians' decision to switch parties after they have won a general election and have become a Member of the Parliament. In parliamentary systems with proportional representation and no split-ticket voting, voters cast their votes for a political party, and not for any particular candidate. If an elected Member of the Parliament (MP) changes party affiliation after being elected, s/he essentially offers his/her seat in the Parliament to another (destination) party. This means that voters who have voted for the original party of the party-switching MP have lost their voice in the Parliament. A switch of an MP from one party to another after an election results in the weakening of the parliamentary power of the party which lost that MP's seat in the Parliament, and can even result in the change of governments. Heller and Mershon (2009) report several such instances. Although a switch of an MP from one party to another after an election may be considered a betrayal of the votes entrusted in that MP, such moves are not uncommon (O’Brien and Shomer 2013). ${ }^{2}$

There are two hypotheses that can explain the transfer of an MP from one party to another. The first hypothesis is that the MP decides to switch to another party after the election because his/her political philosophy and views on economic and social priorities for the country do not line up any longer with the original party and its voters s/he was elected to represent. Alternatively, the switch to another party is made because of the expected benefits and rents this

${ }^{2}$ O'Brien and Shomer (2013) document that one third of the 239 parties in 20 countries in their analysis experienced at least one defection. 
move would generate. If the former conjecture is the primary reason behind the MPs' decisions to switch parties, MPs' concerns for their re-election prospects and benefits associated with staying in office should have no influence on switching parties. On the other hand, if the MPs switch parties during a Parliamentary term to increase their chances of re-election to the Parliament in the next election (by being affiliated with another political party), this would indicate that it is self-interest, rather than political ideology that is the primary driver of this behavior.

Politician behavior is important to investigate, perhaps more so in emerging democracies and in developing countries, for two reasons. First, the behavior of politicians and voters in these settings may be different from those in developed countries and mature democracies (Brender and Drazen 2005). Second, voter disenfranchisement and distrust in democracy due to political agency problems can have serious political and economic consequences.

Consequently, researchers are increasingly interested in analyzing politician and voter behavior in developing countries and young democracies. Examples range from studies on Paraguay (Finan and Schechter 2012) to Brazil (Da Silveira and De Mello 2011), from Russia (Akhmedov and Zhuravskaya 2004) to India (Khemani 2004).

In this paper we use a new and unique data set from Turkey, which is a middle-income developing country. The data contain detailed information on personal attributes, including age, education, field of study (undergraduate major, or graduate field of study), gender, and political party affiliation of each of the more than 2,000 politicians elected in each district (typically, a city) in five consecutive parliamentary elections between the years of 1991 and 2011. We combine this information with the number of votes received by each party in each district in these elections, and make use of an interesting feature of the official d'Hondt seat-allocation 
formula that determines the winners and the winning margins in election districts. In the application of this formula, ${ }^{3}$ a small shift in the distribution of votes between parties in an electoral district has implications on who gets elected. In other words, the number of seats won by each party in a given district is sensitive to small changes in the vote shares of political parties in that district. This feature of the d'Hondt method introduces an element of randomness to the process of who gets elected to the Parliament from a given district and who loses by a small margin. Thus, it creates election uncertainty. We explain below in detail the specifics of the d'Hondt method and the electoral uncertainty generated by it.

We show that politicians are more likely to switch parties after the election (despite the fact that they won a seat in the Parliament) if they faced election uncertainty. In other words, politicians who had a narrow victory are more likely to switch parties. This result is very robust to various measures of election risk, and accounting for the potential impact of unobservables. In addition, we find the tendency to switch parties rises in MP salaries. Also, the propensity of an MP to jump ship and transfer to another party is higher if the MP is a member of the governing party, but only if the majority of the government in the Parliament is slim (fewer than 25 seats out of 550). Election uncertainty prompts party switching among the less-educated (no graduate degree) and younger MPs. Controlling for the earnings potential of the MPs by their college or post-graduate field of study, or by the quality of the university they graduated from, does not change these results. However, we find that for the MPs whose education is a college degree or lower, electoral uncertainty prompts party switching when the quality of the MP's alma mater is low.

\footnotetext{
${ }^{3} \mathrm{~d}$ 'Hondt method is used in many other countries as well, including Austria, Argentina, Bulgaria, Japan, Paraguay, Colombia, Poland, Israel, Belgium and Finland. This method is equivalent to the Jefferson method, devised by Thomas Jefferson in 1792.
} 
We further show that politicians switch parties to improve their ex-ante re-election probability in the following election. Specifically, we find that the party-switching politicians are nominated by their new (destination) parties in the next election in districts and/or ranks on party tickets that are more favorable to their re-election chances. We find that party switchers change parties so that they move towards the median voter on the ideological spectrum.

Barro (1973) and Ferejohn (1986) suggested that voters (principals) can minimize the moral hazard of the elected representatives (agents) through re-election decisions. ${ }^{4}$ In models of retrospective voting, voters can evaluate the performance of the incumbent and vote in the next election to retain or replace the incumbent (Persson et al. 1997). ${ }^{5}$ Thus, retrospective voting is a vehicle through which democratic accountability can be established (Besley 2006). ${ }^{6}$

We investigate whether dishonest politicians, who betrayed their voters and switched parties, get reprimanded by voters in the next election. If voting is a mechanism through which citizens select leaders who will govern honestly (Fearon 1999), then voters should oust politicians who abuse the trust of voters. In other words, elections could be a discipline device for the incumbents. For example, Ferraz and Finan (2008) show that in Brazil, publicly releasing audit reports of municipalities had a significant impact on election outcomes of incumbents, indicating that the politicians who violated the public trust are punished by voters.

\footnotetext{
4 Efficiency wages may be another device that can be used to align voter and politician interests (Becker and Stigler 1974). Recent research has investigated the impact of politician salaries on their work effort and quality (Gargliarducci and Nannicini 2013, Mocan and Altindag 2013, Caselli and Morelli 2004, Besley 2004).

${ }^{5}$ Repeated voting can also be a mechanism whereby voters evaluate and select better-performing politicians (Ashworth 2005).

${ }^{6}$ The standard approach is to investigate whether voters consider improvements in macroeconomic conditions as indicators of the quality of the elected politicians decide by retrospective voting on whether to re-elect or replace them (Nordhaus at al. 1989), and whether voters "vote by the pocketbook" (Brender and Drazen 2008, Lewis-Beck, Nadeau and Elias 2008, Markus 1988, Fair 1978).
} 
We find that party-switching politicians are slightly more likely to get re-elected in the next election. This suggests that dishonesty is being rewarded, rather than punished by voters. However, it should be kept in mind that the voters who are rewarding the party-switching politicians are those who are the supporters of the destination party (the party to which the MP has switched).

In complementary analyses, we investigate how the vote share of each political party changes between elections in each district. Consistent with the finding that party switchers are more likely to get elected, we find that in the election for an upcoming Parliamentary term, if a party's ticket contains a politician who has served as an MP for another party in the immediately preceding Parliamentary term, the vote share of that party in that district increases in comparison to the previous election, holding constant other determinants. This could be because voters consider the addition of the transferred politician to their party's ticket as a sign of quality or power of their party. It could also be due to the electoral system: voters can only vote up-ordown for the entire ticket. Thus, another interpretation of this last result could be that voters of the destination party do not abandon their party to punish the politician who switched to the destination party, presumably because the utility obtained from their party's success in the election outweighs the disutility of voting for the party-switching politician.

To account for the potential impact of unobservables, we implemented the procedures suggested by Altonji et al. (2005) and Oster (2014). The results confirmed our findings and demonstrated that, if anything, our reported estimates may be an underestimate of the true impact of election uncertainty of party switching. Finally, an RDD analysis produced the same conclusion. 
These results point to forward-looking behavior of politicians regarding their strategy to win future elections, and show that politicians switch parties primarily for career concerns and the financial benefits that are associated with longer tenure in the Parliament. The results also signify that competition between political parties continues after the election, in the form gaining seats in the Parliament by transferring politicians who have won elections as representatives of competing parties. This constitutes another dimension of the political agency problem.

Section II provides information on the structure of the election system, and Section III describes the empirical framework. Section IV presents the data, Section V includes the results. Section VI is the conclusion.

\section{The Structure of the Election System}

Proportional representation is the most prevalent election system in the world. It is being used in 38 countries in Europe, from Austria to Iceland, from Italy to Switzerland; and in 16 countries of the Americas, from Argentina to Colombia, from Brazil to Chile. ${ }^{7}$ If the electoral rule in proportional representation is based on close-list or party list system, each party submits a list of "N" candidates (ordered from 1 to $\mathrm{N}$ ) in a given district prior to the election, where "N" is the number of contestable seats in that district. Voters cast ballots for a particular party, not for any given candidate. Using a seat-allocation formula based on vote-shares of parties, the number

\footnotetext{
${ }^{7}$ The European countries that use proportional representation are: Albania, Austria, Belgium, Bosnia and Herzegovina, Bulgaria, Croatia, Cyprus, Cyprus (North), Czech Republic, Denmark, Estonia, Faroe Islands, Finland, Greece, Greenland, Iceland, Italy, Kosovo, Latvia, Liechtenstein, Luxembourg, Macedonia, Moldova, Montenegro, Netherlands, Netherlands Antilles, Norway, Poland, Portugal, Russia, San Marino, Serbia, Slovakia, Slovenia, Spain, Sweden, Switzerland, Turkey. Central and South American countries using this system are: Argentina, Aruba, Brazil, Chile, Colombia, Costa Rica, Dominican Republic, El Salvador, Guatemala, Guyana, Honduras, Nicaragua, Paraguay, Peru, Suriname, Uruguay. The countries in Africa, Asia and Oceania using proportional representation are: Algeria, Angola, Benin, Burkina Faso, Burundi, Cape Verde, Equatorial Guinea, Guinea-Bissau, Morocco, Namibia, Rwanda, Sao Tome and Principe, South Africa, Togo, Tunisia, Bhutan, Cambodia, Fiji, Indonesia, Iraq, Israel, Kazakhstan, Kyrgyzstan, Mongolia, Palestine, Sri Lanka,Timor-Leste.
} 
of seats won by each party ranges from 0 to $\mathrm{N}$. Once the number of seats won by each party is determined in each district, parties send their winning candidates from their list to the Parliament in descending order.

Turkish elections are based on closed-list proportional representation system with a $10 \%$ national threshold for representation. ${ }^{8}$ During elections, political parties compete in 85 electoral districts. A district is typically a city although some big cities, such as Istanbul and Ankara, are divided into two or three districts. Each district is allocated a certain number of seats, and the candidates who win these seats become the MPs to represent that district in the Parliament.

Before the elections, in each district every political party determines and officially announces the ranking of its candidates on the party ticket. For example, if a given district is allocated 7 seats in the Parliament, then each party nominates 7 individuals as candidates from that district. Each party ranks these 7 candidates in descending order, where candidate Number 1 is the first person who would be an MP from that party from that district, candidate No. 2 would be the second person to be sent to the Parliament from that party, and so on. After the votes are counted in the district, the d'Hondt formula allocates the 7 available seats between the parties based on the distribution of votes in that district. For example, if a party is entitled to 2 seats in a district that will send 7 MPs to the Parliament, then the first- and second-ranked candidates from that party's list become MPs to represent the party, but the candidate ranked $3^{\text {rd }}$ on the Party list is not elected; nor are the candidates ranked $4^{\text {th }}, 5^{\text {th }}, 6^{\text {th }}$ and $7^{\text {th }}$.

In the d'Hondt method, the number of votes obtained by each party in the district is divided by consecutive positive integers up to, and including, the total number of seats in that district. Parties with the largest quotients win seats. Consider the hypothetical example of a

\footnotetext{
${ }^{8}$ That is, only those parties that have obtained at least $10 \%$ of the nation-wide vote are represented in the parliament, regardless of the outcome in any particular district.
} 
district with 100 voters. Assume that there are 7 seats to be allocated and five competing parties: A, B, C, D and E. Suppose that in the election these parties have obtained 10,13, 19, 25, and 33 votes, respectively. d'Hondt method divides each party's votes by 1, 2, 3, 4, 5, 6 and 7. Parties with the 7 largest quotients win seats. This is illustrated in Panel 1 of Table 1. The seven biggest quotients (highlighted in bold) are 33, 25, 19, 16.5, 13, 12.5 and 11. The quotients 33, 16.5 and 11 are associated with party E. Therefore party E wins 3 of the 7 available seats. The quotients 25 and 12.5 belong to Party D, so Party D wins two seats; and Parties B and C win 1 seat each. As a result, party B's and party C's top ranked candidates are elected as MPs. Party D sends its top 2 candidates to the Parliament, and party E's top 3 candidates are elected as MPs. Party A does not win a seat.

This allocation mechanism has important properties. First, small changes in the distribution of votes can impact the number of seats won by each party. For example, as Panel 1 of Table 1 demonstrates, party B has received 13\% of the votes (13 votes out of 100) and qualified for 1 seat, while Party A has not qualified even though its vote share (10\%) is only 3 percentage points lower than that of Party B.

A better demonstration of this point can be made by comparing the vote distributions depicted in Panels 1 and 2 of Table 1. In both cases, there are 100 voters, and in both cases parties B, C and E received the same number of votes. The only difference between the election results shown in Panels 1 and 2 is that in panel 2, Party D received 23 votes (instead of 25); and these 2 voters moved from Party D to Party A. The resultant d'Hondt calculation is also presented in Panel 2, which shows that the $2 \%$ loss suffered by Party D did not impact the number of seats of Party D (party D still qualified for two seats). On the other hand, this $2 \%$ vote loss of Party D produced a seat in the Parliament for Party A at the expense of a seat for 
Party E. More specifically, this slight shift of votes from Party D to Party A cost one MP to Party E, while Party A gained one seat.

As shown in Panel 3 of Table 1, if 2 more individuals had voted for party A instead of D, the election outcome would have been more different yet: In that case, parties A, B, C and D would qualify for one seat each, while party E would have 3 MPs.

Importantly, because candidates are elected based on their rank on their parties' list, even marginal changes in vote distribution may lead to alterations in who is elected from a given party. For example, under the vote distribution presented in Panel 1 of Table 1, the first-ranked candidates of parties B and C (denoted by B1 and C1), the first- and second-ranked candidates of party D (D1 and D2), and the first three candidates of party E (E1, E2 and E3) will be elected as MPs.

The top panel of Table 2 replicates the election outcomes generated by vote distribution displayed in the top panel of Table 1. The elected candidates, based on this distribution, and their corresponding quotients are re-displayed in the bottom panel of Table 2. Once again, the district sends 7 MPs to the Parliament; thus the politician who ends up with the $8^{\text {th }}$ largest quotient does not qualify to be an MP. The quotient of candidate E3 (the third ranked candidate of party E) is 11 , and it is the $7^{\text {th }}$ largest quotient. So, candidate E3 has won the $7^{\text {th }}$ and the last seat of the district by beating A1 (who is the first-ranked candidate of party A). On the other hand, A1 has the 8th largest quotient (which is 10) in the district, and therefore did not qualify for a seat.

The bottom panel of Table 2 also displays the margins of victory (MV) for each elected MP. MV is the difference between the quotients of each elected candidate and the candidate who just missed qualifying for the last seat from that district. For example, the person who won 
the $7^{\text {th }}$ and the last seat in this district is candidate E3, and her margin of victory is 1 (the difference between the E3's and A1's quotients). Candidate E1 is the first-ranked candidate of party E; her quotient is 33 and therefore her MV is 23 . In some specifications we will use the margin of victory as an (inverse) measure of electoral uncertainty faced by the politician.

The bottom panel of Table 2 also identifies the "last candidate elected" from each party in the district. This person is the lowest ranked candidate who won a seat from that party's ticket. For example, Party E won three seats from the district and therefore the $3^{\text {rd }}-$ ranked candidate of that party (E3) is the last candidate of that party who secured a seat. Similarly, D2 is the last candidate from party $\mathrm{D}$ who won a seat from this district. $\mathrm{C} 1$ is also the last person elected from her party's list. She is the $1^{\text {st }}$ - ranked candidate of party $\mathrm{C}$, but she is also the last one elected on that party's ticket. In some specifications we will employ being "the last person elected" as a measure of electoral uncertainty faced by the elected MP.

Finally, the rank of the candidate on his party's ticket and the number of contested seats in his district allow us to determine the necessary proportion of votes that should be received by that candidate's party for him to have a chance (positive probability) to get elected. Similarly, the sufficient proportions of votes (the percentage of votes that should be received by the party to guarantee a seat for that candidate) are calculated for each candidate. These measures are alternative indicators of election uncertainty faced by the candidates. The details of these measures are explained below. 


\section{Empirical Framework}

Consider politician $(m)$ from party $(p)$ who won an election at time $(t)$ from city $(c)$ to become a Member of the Parliament (MP). Let Party Switch mcpt $_{\text {be }}$ an indicator to represent whether the MP has switched to another political party during the parliamentary term which started after the election at $(t)$. That is, Party Switch ${ }_{m c p t}=1$ if the MP switched to another political party after winning a seat in the election at time $(t)$, but before the following election. The probability of switching parties can be estimated as

$$
\begin{aligned}
\text { Party Switch }_{m p c t}= & \beta \text { Election Uncertainty } \text { Unct }_{m p}+\text { MP Benefits } \text { Bct }_{\boldsymbol{m}} \boldsymbol{\Omega}+\boldsymbol{X}_{m t} \mathbf{\Psi}+ \\
& \lambda_{c}+\pi_{t}+\xi_{p}+\varepsilon_{m p c t}
\end{aligned}
$$

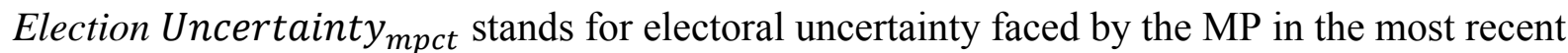
election. It is a measure of how easily the MP was elected from city $c$ after being nominated by party $p$ at election $t$. If the MP has won his/her seat after a competitive race, this indicates that he/she could have lost; and this represents electoral uncertainty in the next election if nothing changes (i.e. if the MP is re-nominated by the same party, from the same district, at the same party rank). We use several measures for electoral uncertainty. For example, we use the Rank of the MP on their party's list when they entered the Parliament for term $t$. Candidates ranked lower on their party list, although they won a seat, had faced smaller probabilities of election. In some regressions, we include Rank as a continuous variable or as a set of indicator variables (e.g. Ranked Second, Ranked Third, etc.). We also use the margin of victory in the election (see Table 2) as an (inverse) measure of electoral uncertainty faced by the politician. In other specifications we use an indicator to represent whether the MP was the last person (lowest ranked) who won a seat from his/her party's ticket. 
We also calculate the necessary and sufficient conditions for each candidate in each district to win a seat. Following the formulation provided by Palomares and Ramirez (2003), the minimum proportion of votes required for guaranteed election of each candidate is calculated as:

$$
\% \text { vote for guaranteed election }=100 \times \frac{\text { Rank }}{\text { Seats }+1}
$$

where Rank is the rank of the candidate on his/her Party's list and Seats represents the number of seats contested in the electoral district. For example, if a party competes in a district with 3 contested seats, then, the first-ranked candidate of the party will be elected for sure if the party receives more than $25 \%$ of the votes $(100 \times 1 / 4)$. In another district with 12 seats, the party has to obtain more than $23 \%$ of the votes in order for its $3^{\text {rd }}$ ranked candidate to be elected (3/13=0.23), and so on. The formula in Equation (2) provides the sufficient share of votes to get elected for each candidate in each election district. Obtaining a vote share above this threshold guarantees election of the candidate, regardless of the votes obtained by other parties. ${ }^{9}$

For each candidate, we also calculate the minimum share of votes (the necessary share) above which his/her election probability becomes positive, using the formula below:

$$
\text { Minimum \% vote for Prob(Election) }>0=100 \times \frac{\text { Rank }}{\text { Seats-1+Parties }}
$$

where Parties represents the number of parties competing in the district. For example, consider a district with 2 contested seats, and 3 competing parties in this district. In this case, no party that obtains less than $25 \%$ of the votes will win any seats in this district. In other words, even for the

\footnotetext{
${ }^{9}$ Of course, some candidates could be elected even if their party receives votes below this calculated threshold. This is because, the threshold calculated by Equation (2) only differentiates between election probabilities of 1 versus less than 1. For instance, in the example demonstrated in Table 1 under Distribution 2 (five parties competing for seven seats), the minimum vote share for guaranteed election for a first-ranked candidate is $12.5 \%$ (as $\frac{1}{7+1}=0.125$ ). In other words, to receive $12.5 \%$ of the votes would be sufficient for any first-ranked candidate in that district to secure a seat, but in that example Party A's first-ranked candidate is still elected, even though party A received 12\% of the votes.
} 
first-ranked candidate of a party to have any chance of election, her/his party has to obtain at least $25 \%$ of the votes. In another district with 12 seats and 3 parties competing, a party has to gather at least $21 \%$ of the votes for their $3^{\text {rd }}$ ranked candidate to have a chance of getting elected. This is the necessary condition for each third-ranked candidate to have a shot at being elected.

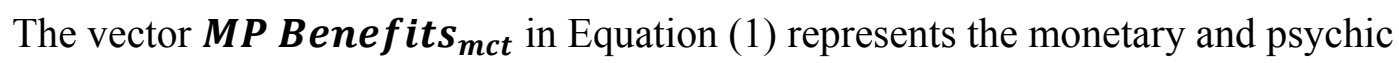
benefits associated with being an MP. We use the relative MP salary as a measure of financial benefit to being an MP. Nominal MP salaries are increased by the Parliament regularly, typically twice a year. The rate of increase in salaries, however, varies from year to year. ${ }^{10} \mathrm{We}$ employ the ratio of MP salaries to per capita income of the city from which the MP was elected. Thus, the measure of salary exhibits variation both over time and across MPs.

If the MP is a member of the party that has formed the government, the MP's seat is more valuable to the opposition parties because a transfer of the MP to one of the opposition parties weakens the power of the government, and increases the power of the opposition. Thus, we control for whether the MP is the member of party (parties) that runs the country (Member of Government Party).

The vector $\boldsymbol{X}_{\boldsymbol{m} t}$ stands for personal attributes of the MP. Some of these attributes, such as age at the time of election, may impact the probability of switching parties because they are related to the discounted future benefits of staying as an MP (Alesina et al. 2015). Other variables, such as gender, may have an impact if females are systematically different from males in terms of the honesty of their actions. For example, holding constant other determinants,

\footnotetext{
${ }^{10}$ For example, in 1991, the monthly real MP salary (indexed to 2010 prices) was equivalent to TL14,397 Turkish Lira (TL). In 1995 it was TL 6,005, but went up to TL12,669 in 1999. Monthly MP salaries were TL12,629 in 2002 and TL10,447 in 2007. In 2010 one USD was equivalent to 1.5 TL.
} 
criminal propensity of women are lower than that of men (Mocan and Rees 2005, Jacob and Lefgren 2003), and women are shown to be different than men in other dimensions, such as risk aversion (Croson and Gneezy 2009).

$\boldsymbol{X}_{\boldsymbol{m} t}$ includes the level of education of the MP because education determines outside options. Education can also impact values and preferences, which can influence the decision to switch parties and betray the voters. Following Besley et al. (2011), schooling is measured by whether the MP has a master's degree or a doctorate $(M A / P h D)$, and whether the MP has obtained a college degree outside of the country (School Abroad). We also utilize information on undergraduate major or the area of graduate study of the MP.

Party-electoral district level control variables are the share of votes obtained by the MP's party in the MP's electoral district (Party's Vote Share) and the number of contested seats in that district (Seats in District). We also control for whether the MP was elected for the first time (Freshman) because the tendency to switch parties may be impacted by networks that may be generated through the experience in the Parliament.

When nominating their candidates, party leadership may rank them according to the candidates' perceived loyalty to the party's cause (Galasso and Nannicini 2014). If parties nominate more loyal candidates at higher ranks on the list, or nominate loyal candidates in districts that are more favorable for their election, and if the probability of party switching decreases with loyalty, then our estimated effect of party rank may partly capture the effect of party loyalty. We include a variable to indicate whether the MP was Elected from the same party in a previous election. Longer tenure in a party represents an individual's loyalty to that party's cause. We also control for whether the MP is a member of the Cabinet (a Minister of the Government). Being a Cabinet Member provides additional prestige and visibility, as well as 
opportunities for networking that can be turned into future financial rewards. These positions are usually afforded to individuals who have long-term affiliations with the party. It is also possible that party leadership ranks a candidate lower on the ticket if the candidate is perceived to be too ambitious for his/her career. We collected data to proxy the "ambition" of the MPs. Specifically, we controlled for the extent of the visibility of the MP in the Parliament, measured by the number of activities, such as speeches delivered, and questions asked in the Parliament.

Culturally, voters in some cities may be more or less tolerant about politicians' switching parties and the same may be true for the supporters of certain political parties. These unobserved city and party attributes will be controlled for by including city and party fixed-effects $\left(\lambda_{\mathrm{c}}\right)$. We also add parliamentary term fixed effects $\left(\pi_{\mathrm{t}}\right)$, and political party fixed effects $\left(\xi_{\mathrm{p}}\right)$.

We hypothesize that higher uncertainty about re-election prospects under the current party affiliation would prompt the MP to switch to another party and be nominated from that new (destination) party in the next election. In other words, if the MP perceives his/her chances of being re-elected as low with the current party, the propensity to switch alliance to another party is higher. This assumes that, from the point of view of the MP, a condition for the switch is the assurance that the new party would nominate the MP at a district and/or position on the party list that would provide ex-ante a higher chance of election during the next (upcoming) election in comparison to the election he/she just won. So, a testable hypothesis is whether those MPs who switched parties are being nominated at positions for the following election so that their ex-ante election probabilities are higher in comparison to what they have experienced in the preceding election. We test this hypothesis and provide strong support for it. Specifically, we investigate the electoral consequences of party switching for the MP in the following election, using the specification below: 


$$
\begin{aligned}
& \text { Next Election Outcome } e_{m p c t+1}=\beta \text { Party Switch } \text { mpct }_{\text {PPBenefits }}+\text { MPt }_{m+} \boldsymbol{\Omega} \\
& \qquad \boldsymbol{X}_{m} \boldsymbol{\Psi}+\lambda_{c}+\pi_{t}+\xi_{p}+\varepsilon_{m p c t}
\end{aligned}
$$

where Next Election Outcome $e_{m p t+1}$ stands for the election outcome of the MP $(m)$ pertaining to the next parliamentary term in election year $(t+1)$. The analyses, based on Equation (4), allow us to investigate how future election outcomes are different between those MPs who switched parties (Party Switch mpct $=1$ ), and those who did not. We use several variables for Next Election Outcome $e_{m p c t+1}$. For example, we consider whether party switchers are more likely to run for re-election, how favorable the switchers are ranked by the new (destination) parties in the next election, and whether they are actually re-elected in the next election. The variables included in the vector $\boldsymbol{X}$ are same as those used in equation (1).

Finally, we also analyze how a party's election success in a district is impacted by having on the ticket an MP who was transferred from another party. In these regressions the unit of observation is a city-election-party. Specifically, consider Equation (5) below

(5) $\%$ Vote in District $_{p c t}=\gamma \%$ National Vote $p t+\theta$ Gov $^{\prime}$ tParty $_{p t}+\lambda_{c}+\pi_{t}+\xi_{p}+v_{p c t}$ where the proportion of votes received by party $(p)$ in city $(c)$ in election year $(t)$ is depicted by $\%$ Vote in District $_{p c t}$, which is a function of the nation-wide success of the party $\left(\%\right.$ National Vote $\left._{p t}\right)$ and whether the party entered the election as the Governing Party (Gov't Party $_{p t}$. The political sentiment in the city, which impacts the number of votes received by the party, is captured by city fixed effects $\lambda_{\mathrm{c}}$. Election year fixed-effects are captured by $\pi_{\mathrm{t}}$, and party fixed-effects are represented $\xi_{\mathrm{p}}$.

Writing Equation (5) for the next election year $t+1$ and taking the first-differences, we estimate Equation (6) below 


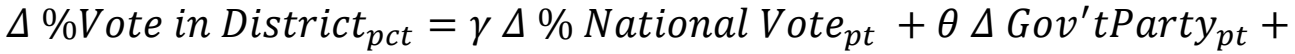

$$
\begin{aligned}
& \varphi \text { MPs } \text { Gained }_{p c t}+\delta_{t}+\mu_{c}+\tau_{p}+u_{p c t}
\end{aligned}
$$

where $\Delta$ stands for the change in the relevant variable between the two consecutive elections. ${ }^{11}$ Although district fixed-effects and party fixed-effects drop out from equation (6), we nevertheless keep them to absorb any residual unobserved variation. In equation (6) the variable MPsGained $_{\mathrm{pct}}$ stands for the number of MPs who switched to party (p) from other parties between the two elections, and are now nominated from party $(p)$. Thus, we analyze how the vote share of party $(p)$ changes from one election to another and whether this change is impacted by whether or not the party's ticket in that election in that city contains an MP who was transferred from another party.

\section{Data}

Our data set is composed of individuals who are elected as members of the parliament (MPs) in the Grand National Assembly of Turkey in parliamentary terms 19 to 23 (1991-2011). We analyze five consecutive elections for which complete data are available. Our outcome variable Party Switch denotes whether an MP's beginning-of-term party is different from their end-of-term party. In our data set, out of 2,208 MP-term observations that entered into our regressions, there are 254 party switches $(12 \%) .{ }^{12}$ The distribution of MPs by their beginning-ofthe-term and end-of-the-term parties is presented in Online Appendix Tables 1 and 2,

\footnotetext{
${ }^{11}$ More accurately, elections take place 4 years apart, and the change in a variable $\mathrm{Y}$ between elections $\left(\Delta \mathrm{Y}_{\mathrm{t}}\right)$ represents $\mathrm{Y}_{\mathrm{t}}-\mathrm{Y}_{\mathrm{t}-4}$

${ }^{12}$ Some MP-term observations are omitted. Specifically, the MPs who passed away before the end of the term are not in the analysis, so are the MPs who resigned from their party but remained as independent (not affiliated with any party) or who were forced to resign by the constitutional court. An MP's switch to another party is not counted as a party switch if their initial party is shut down by the constitutional court. Some parties changed their names. Such name changes are also not considered as party switches either.
} 
respectively. The number of MPs who switched parties and their share in the parliament are presented in Table 3 for each parliamentary term.

Party switch information is obtained from three sources: 1. Parliamentary Bulletin (Meclis Bulteni) - the official monthly journal of the Turkish Parliament; 2. meclishaber.gov.tr the official news web site of the Turkish Parliament. For the $23^{\text {rd }}$ term (2007-2011), information on whether an MP has switched parties was not available in these sources. Therefore, for this particular Parliamentary term, we determined each MPs party affiliation using the latest roll-call voting data.

We obtained the rank of each MP as he/she was listed on the party list before an election from the official gazette of the Parliament (Resmi Gazete). Based on this information, we constructed the variable Rank which is the rank of an MP on the party's list of candidates in the electoral district. This variable is continuous. We also generated variables that indicate whether the MP is ranked Second, Third, Second or Lower, Third or Lower and Fourth or Lower on their party list. $42 \%$ and $24 \%$ of the MPs were ranked as first- and second-highest candidates in their party list, respectively. The remaining $34 \%$ were listed as third-ranked or worse.

We augment our data set with MPs' personal characteristics and their party’s election results. Variables Female, Age $>50$ and $M A / P h D$ indicate whether the MP is female, older than 50 years old and has completed a degree beyond college. School Abroad indicates whether the MP has obtained a degree from a school outside Turkey. This variable potentially captures both the quality of education an MP has received and personal wealth of the MP, as getting schooling abroad is costlier than going to school in Turkey. Cabinet Member denotes whether the MP also served as a minister in the cabinet in the parliamentary term. Freshman takes the value of one if the MP has not been elected to the Parliament previously, and zero otherwise. Seats in District 
measures the number of seats contested in the electoral district that the MP is representing. Party's Vote Share is the share of votes obtained by the party of the MP's electoral district. The data source of personal characteristics is the profiles of the MPs in Turkish Parliament web site. Election results data are obtained from the official gazette (Resmi Gazete). The summary statistics and the descriptions of the variables are presented in Table 4.

\section{Results}

\section{Determinants of Party Switching}

The results, obtained by estimating Equation (1) by probit are presented in Table 5. The entries are marginal effects, and standard errors are clustered at the MP level. The outcome variable is Party Switch. This variable takes the value of one if the MP switched to another party after being elected. In addition to the variables listed in the table, regressions include indicators for MPs' initial party affiliation, parliamentary term fixed-effects and city (which is the same as election districts, with the exception of three largest cities which are divided into 2 or 3 district) fixed-effects.

In the model reported in column (1) of Table 5, electoral uncertainty faced by the MP is measured by the variable Rank, which is the rank of the MP on the party's election list. MPs with higher values of Rank were ranked lower on their party's list of candidates. Thus, they had smaller chances of being elected, and faced greater uncertainty in comparison to a candidate from the same party but who was ranked higher on the list. Column (1) shows that the MPs who were ranked towards the bottom of their party list are more likely to switch to other parties before the end of the Parliamentary term, in comparison to those who are ranked higher. 
Forty-two percent of the MPs are ranked at the top of their ticket. This means that having been ranked as the second or the third candidate on the ticket is associated with substantial uncertainty about election prospects. ${ }^{13}$ In columns (2) to (4) of Table 5, we use indicator variables instead of a continuous measure of party list rank. For example, the variable Ranked $2^{\text {nd }}$ or Lower takes the value of one if the MP was ranked second, third or lower on the party ticket.

The results show that MPs who were ranked second, third, or lower are more likely to defect from their original party and switch to another party in comparison to the top ranked candidates on their parties' lists. For example, column (3) shows that, compared to their counterparts who are ranked first, second-ranked MPs are 2.3 percentage points more likely to switch parties, and the MPs who got elected as the $3^{\text {rd }}$ ranked candidate or lower, are 2.9 percentage points more likely to switch.

In columns (5) and (6), we utilize the vote thresholds in the district implied by the d'Hondt method as alternative measures of election uncertainty faced by the MP. As explained in Section II, we calculate the threshold vote share above which a candidate is definitely elected (the sufficient share of votes for that candidate in that particular rank to be elected), and the threshold vote share above which the candidate has non-zero probability of election (the necessary proportion of votes for this candidate to be elected). Because these thresholds incorporate the number of contested seats and the number of competing parties, they allow for a comparison of election uncertainty of MPs across districts and over time. ${ }^{14}$ Higher values of

\footnotetext{
${ }^{13}$ This of course in not true in very large districts, such as in Istanbul, where a district produces on average 17 MPs. Even in such mega-districts, the median of Rank of the elected MPs is 3.

${ }^{14}$ For example, to have a non-zero probability of election, the party of a second ranked candidate has to obtain at least $20 \%$ of the votes in an electoral district, say District 1, where 6 parties are competing for 5 seats. In another district, District 2, where the same number of parties competes for 6 seats (one more compared to District 1), a party has to obtain at least $18 \%$ of the votes in order for their second ranked candidate to have a shot at election. Notice that, holding party-list rank constant, in District 1, where there are fewer available seats, the candidate's chance of
} 
these threshold variables signify greater uncertainty and tightness of the election the MPs have faced. The coefficient of Min \% Vote for Guaranteed Election in column (5) of Table 5 suggests that a 10 percentage point increase in the threshold vote share MP has faced in the election increases the probability of his/her switching parties by 1 percentage point. Similarly, an MP who faced a higher threshold for non-zero election probability is more likely to switch parties (coefficient of Min \% Vote for Election prob $>0$ in column 6).

In column (7), we measure electoral uncertainty by the Margin of Victory (MV) of the MP. As demonstrated in the bottom panel of Table 2, MV is the distance between the elected MP's quotient (determined by the d'Hondt formula) and the quotient of the cutoff candidate, who just missed getting elected. A larger value of the MV indicates that the MP has won the election with a larger cushion. Consequently, as Table 5 shows, a larger margin of victory reduces the propensity to jump ship and switch parties after the election.

Column (8) of Table 5 presents a different specification. Here, the model includes a dummy variable Elected as the Last Person on the Ticket, which takes the value of 1 if the MP was the last person elected from his party's ticket in that district. For example, in the example of the bottom panel of Table 2, the first-ranked candidate of party B (B1) is elected as an MP, and he is also the lowest ranked person elected from his party, because he is the only one elected from party B. So, for him, Elected as the Last Person on the Ticket=1. On the other hand, in that same table we observe that Party E produced three MPs. Therefore Elected as the Last Person on Ticket takes the value of 1 only for E3, the $3^{\text {rd }}$-ranked MP of party E.

Consistent with other specification, column (8) shows that if the MP is the last person elected from his party's ticket in a district, he/she is 2 percentage points more likely to switch election chances. The construction of these variables is explained in Data section. 
parties after the election in comparison to another MP who was elected from the same district, in the same election but not as the last person elected.

These results demonstrate that electoral uncertainty, regardless of how it is measured, has a positive impact on the politicians' propensity to jump ship and switch parties, despite winning elections.

The variable, titled "Relative Salary" is the ratio of real MP salary to the per capita income in the city from which the MP was elected. MP salaries are periodically adjusted upwards by the Parliament, and there is variation in per capita income between cities. Thus, Relative Salary varies both over time and between cities. Table 5 shows that an increase in MP salaries in comparison to per capita income has a positive impact on the propensity to switch parties, likely because an increase in salary makes the MP's post more attractive.

Members of the Parliament who are also members of the cabinet are less likely to switch to another party. This is arguably because, Cabinet Members have access to government resources, and defecting from their current party may reduce opportunities to obtain governmental pork (Desposato 2006). Members of the Parliament who were 50 years of age or older when they were elected, are less likely to switch parties. This could be because it may not pay off to switch parties and start off anew at a different party when time left to retirement is shorter. This finding is consistent with Alesina et al. (2015).

Freshman parliamentarians are less likely to switch parties. These MPs are elected to the parliament for the first time, and presumably because of this, they did not have enough time to network and make connections with competing parties to be able to switch their party affiliation. Those MPs who have received a college or graduate degree outside Turkey are less likely to switch parties. To receive a college degree abroad could be an indicator of wealth, or superior 
academic performance in high school. MPs who obtained a degree abroad are more likely to be a member of a wealthy family compared to MPs who went to college in Turkey, because attending school abroad is more expensive compared to obtaining a degree in the country. Alternatively, an MP could obtain a degree abroad with the support of a scholarship thanks to their superior academic performance in school. In either case, wealthy or academically successful MPs have better outside options in the labor market. Those who are elected multiple times from the same party (and have not switched parties) are more likely to be loyal to the party. The coefficient of Elected from the Same Party Before is negative and significant in all specifications, but omitting this variable, which captures party loyalty, has no impact on other coefficients.

An interesting result in Table 5 is the impact of Member of the Government Party. This variable takes the value of one if the MP's party is the governing party in the Parliament, either as the majority party or as part of a coalition government. The results show that if MP is the member of the majority party (the governing party), then his/her probability of switching parties is seven percentage points larger. This is likely because it is a more attractive proposition for the MP to transfer to another party if he/she is a member of the majority party, because such a move weakens the government, and strengthens the opposition. Furthermore, it is expected that the impact is larger when the margin of the majority of the government is smaller. ${ }^{15}$ We estimated the model in column (2) of Table 5 by interacting Member of Government Party with the Size of

\footnotetext{
${ }^{15}$ For example, if the Parliament consists of 550 seats, then for a party to be the government, it has to have won more than 275 seats. Consider two scenarios. In both cases, a particular party won the election, but assume that in the first scenario it secured 285 seats in the Parliament, whereas in the second case it gained 300 seats in the election. The difference in seats between the government party and the opposition is narrower in the first case. More specifically, if only 10 MPs of the governing party switch sides and transfer to the opposition, there government would fall as it does not maintain the majority any longer. This suggests that the impact on party switching of being an MP of the governing party should be larger, the narrower is the majority of the governing party.
} 
the Majority, where the latter is measured by (Number of seats of the government partyTotal seats in parliament/2). The impact of Member of Government Party, evaluated at different majority levels, is presented in Figure $1 .{ }^{16}$ The solid line demonstrates the marginal effects and the dashed lines represent the $95 \%$ confidence internal. MPs have a larger propensity to change party allegiance if the majority of the government is narrow. If the government has a majority cushion of at least 25 seats in the Parliament, then being a member of the governing party has no impact of party switching. In other words, the value of an MP who belongs to the governing party is zero when the government has $50 \%$ of the seats +25 or more votes in the Parliament.

Recall that Margin of Victory (MV) is the distance between the elected MP's quotient, calculated by the d'Hondt formula and the quotient of the Cutoff candidate (see Table 2). A smaller value of MV signifies a greater uncertainty of election. We re-estimated the models for the probability of switching parties, shown in Table 5 using only the MPs who got elected with $M V \leq 5$ and alternatively, with $M V \leq 3$. The MPs who got elected with such small margins have experienced particularly noisy elections that could have resulted differently. The results are presented in Table 6 for selected specifications. As before, having a low ranking on the party ticket increases the propensity to change parties after the election, but unsurprisingly, the impact of rank is larger among this group of MPs, compared to the whole sample analyzed in Table 5.

\section{Alternative Specifications}

In Table 7 we present alternative specifications to investigate the robustness of the results. In column (1) of Table 7 we include a dummy variable to indicate if the MP was ranked

\footnotetext{
${ }^{16}$ Using other specifications reported in Table 5 provided almost identical results.
} 
$2^{\text {nd }}$ or lower on the ticket, another dummy to indicate if he/she was the last person elected from that party ticket in that district and the interaction of these dummies, along with all other controls. Panel A of the table reports the marginal effects of the rank variable, and Panel B reports the difference of the marginal effects of the rank variable evaluated when the MP was/wasn't elected as the last person (Elected as the last person=1 and $=0$ ). The results show that holding constant the rank of the MP on his/her party's ticket, he/she is more likely to switch parties if he/she was elected as the last person on the ticket.

Are the politicians who were listed at the top of the party ticket different?

It can be argued that the politicians who were listed at the top of the party ticket in an election district could be different than those who were listed lower. More specifically, those who were listed at the top of the ticket could be more loyal to the party than those ranked lower on the ticket. In that case, it is the party loyalty, rather than election uncertainty would be the reason for party switching. Columns 3-5 of Table 7 report models estimated by excluding MPs who are ranked at the top of their party tickets. Thus, this sample contains those who are elected as $2^{\text {nd }}$ or lower-ranked candidates. The left-out category in these models is those who are ranked $2^{\text {nd }}$ on their party ticket. Column (3) shows that, the propensity to switch parties is higher for those MPs who are ranked fourth of lower in comparison to those who are ranked third or second (which is the left-out category). Columns (4) and (5) show that as the difficulty of winning the election goes up (represented by Min \% Vote for Guaranteed Election, and Min \% Vote for Election Prob $>0$ ) the probability of switching parties goes up, although the coefficient is not significant at conventional levels in column (5). 
Finally, columns (6) and (7) of Table 7 display the models that are estimated using only the sample of first-ranked candidates. These are the MPs who were listed at the top of their party list in their district. These individuals may be listed as the top candidates because they may have stronger ties to the party and they may be perceived as more loyal (less likely to jump ship) by party leaders. Still, even in this group, election uncertainty, represented by an increase in the proportion of votes necessary for election has a positive impact on the propensity to switch parties.

\section{Ambition?}

It is possible that more ambitious politicians are more likely to switch parties. Ambition is not observable, but a politician's ambition about his/her political career may be correlated by his/her activities in the parliament. We collected data on the number of speeches on the floor, oral or written questions delivered, motions and proposals submitted in each parliamentary term. This variable, titled Effort, is included to the models as an additional control. The mean of this variable is 42 . The results are presented in Table 8 . The effort of the politicians in the parliament (after the election) is positively related to the propensity to switch parties, although mostly statistically insignificant ${ }^{17}$; but the effect of election uncertainty on the propensity to switch parties is not impacted by accounting for effort.

\footnotetext{
${ }^{17}$ The variable Effort in Table 8 is re-scaled as Effort/100.
} 


\section{Unobservables?}

These findings provide evidence for a positive causal effect of election uncertainty on party switching. It could be argued, however, that politicians are selected into situations of election uncertainty (ranks on the ticket) because of unobservables. In other words, those MPs who faced higher election uncertainty might be different from other MPs in unobservable ways. We applied the procedures suggested by Altonji et al. (2005), and Oster (2014) to investigate this premise. The results, presented in Online Appendix 2, show that our reported estimates may be an underestimate of the true impact of election uncertainty of party switching. We also implemented an RDD (reported in Online Appendix 3), which confirmed the results obtained from other analyses.

\section{Does Election Uncertainty Impact the Propensity to Switch Parties Change by Age?}

In Table 5 we reported that switching parties is less likely for politicians older than 50 . To further investigate the extent to which politician behavior is impacted by age, we estimated various versions of the model by measuring age in different ways. We only report results where

electoral uncertainty is measured by whether the MP was ranked $2^{\text {nd }}$ or Lower on the party ticket. The results are reported in Table 9. Column (1) replicates the model reported in column (2) of Table 5. In column (2) age is measured as a continuous variable, and in column (3) it is measured by a sequence of dichotomous indicators. In each case, age has a negative impact on the propensity to switch parties, and the specification in column (3) suggests that the effect is monotonic.

In columns (4) and (5) of Table 9, we run the models by dividing the sample into two groups: politicians younger than 50 , and those who are 50 or older. We find that electoral 
uncertainty, measured by the rank on the party ticket, has no impact on the propensity to switch parties for the politicians who are 50 or older (column 5). The point estimate is practically zero. On the other hand, having been ranked low on the party list has a significant impact on party switching among politicians who are younger than 50 .

Parliamentarian salaries (Relative Salary) have a positive impact on the propensity to switch parties for those MPs who are younger than 50, but salary does not impact the propensity to switch parties for those who are 50 or older. Being a Member of Cabinet reduces the propensity to change party allegiance, but this is driven by politicians younger than 50 . These results indicate that younger politicians behave in a more opportunistic way to increase their reelection prospects, and they are consistent with Alesina et al. (2015) who analyzed data on Italian mayors and reported that younger mayors attract larger transfers from higher levels of government and increase investment spending in pre-election periods, thus creating a political business cycle.

\section{Does Electoral Uncertainty Impact the Propensity to Switch Parties by Educational}

\section{Attainment?}

To investigate whether electoral uncertainty has a differential impact on those MPs who are highly educated in comparison to those who are less educated, we divided the sample into two groups: those who have a graduate degree (a Master's or a $\mathrm{PhD}$ ) versus those who have at most a college degree. About 1/3 of the sample has graduate degrees. Of those who have no graduate degree, 87 percent have a college degree. Table 10 summarizes the results. Interesting regularities emerge. Among the sample of MPs with an MA or PhD degree (columns 1 and 2 of Table 10), having faced a close election has no impact on the propensity to change parties after 
the election. On the other hand, the impact of electoral uncertainty on party switching is significant among the MPs whose terminal degree is a college diploma or lower (columns 3 and 4 of Table 10).

As columns (1) and (2) of Table 10 indicate, if a highly-educated MP is a cabinet member, this reduces his/her propensity to switch parties. On the other hand, cabinet membership does not deter an MP from switching parties if the MP is relatively low-educated. This is not because of lack-of variation in cabinet membership among the lower-educated group. In this group, the mean of Cabinet Member is 0.10 (it is 0.17 among the group with graduate degrees). Interestingly, the impact of gender exists only among those MPs who are relatively less educated. Female MPs are more likely to switch parties if they are less educated (no postgraduate degree).

To investigate whether outside financial options of the MPs have an impact on the probability of switching parties, we obtained information on undergraduate major of each MP who has a college degree, and the graduate fields of study for those who have a graduate degree. The field of study is broadly correlated with income. For example, engineers have higher earning power than teachers; those who have a law degree differ in potential earnings from those who have a science degree, and so on. Using information obtained from official Parliamentary records, we classified MPs into 10 categories as follows. Those who have a degree in 1) Basic Sciences (Chemistry, Physic, Biology, etc.) 2) Computer Science, Electrical Engineering, Math 3) Other Engineering 4) Health Sciences (MD, Veterinarian, Pharmacist) 5) Education (Teachers) 6) Economics and Management 7) Law School 8) Social Sciences (sociology, 
psychology, etc.) 10) Other fields of study including ex-military and police. ${ }^{18}$ The details of specific majors included in each category are provided in the notes to Table 11.

Results of the models that control for field of study are reported in Table 11. Columns (1) and (2) report the results obtained from the whole sample. In this specification the left-out category includes those who have no college degree (high school degree or lower). The impact of electoral uncertainty of switching parties is not influenced by controlling for the differences in earnings potential, and the field of study has no impact on the propensity to switch parties.

Columns (3) and (4) display the results that use the sample of MPs who have graduate degrees. Those who have a college degree or lower are dropped from this sample. The results show that, as before, among the group of MPs with a graduate degree, electoral uncertainty has no impact on party switching. Columns (5) and (6) present the results in the sample of MPs for whom the terminal education is a college diploma. The results show that, consistent with previous findings, in this sample of relatively-low educated MPs electoral uncertainty impacts party switching.

Finally, we control for the quality of the university the MP has attended. There exists substantial variation in educational quality between universities and there is higher demand by students for high quality institutions. Prospective college students (typically high school seniors) take a centralized nation-wide university entrance exam. The scores on this exam determine the placement of students to universities and academic departments. We measured university quality by the average university entrance exam score of students admitted to that university. A higher

\footnotetext{
18 The means of the variables are as follows: Sciences: 0.04, Computer Sci/Elect Eng/Math: 0.03, Other Eng: 0.16, Health Sci: 0.11, Education: 0.05, Econ/Management: 0.22, Law: 0.18, Social Sci: 0.09, Military/Police: 0.01, Other: 0.02, High School Degree or Lower: 0.09
} 
score represents a more selective university. ${ }^{19}$ The results, which are reported in Online Appendix 1- Table 2, are consistent with those reported in Tables 10 and 11. Those MPs who graduated from better universities are less likely to switch parties, but electoral uncertainty impacts party switching only among those who are relatively less educated.

We ran a specification where the dummy that identifies if the MP was ranked second or lower on the party ticket is interacted with the quality index of the university he/she graduated from. The index of university quality is, as before, the average score of students admitted to that university following the university entrance exam. The marginal effect having been ranked as second or lower on the party ticket, evaluated at different quality levels of the university, is presented in Figure 2 (for those who have no post-graduate degree). The impact of electoral uncertainty on party switching is positive if the MP is a graduate of a less-selective university (the quality index of the institution is lower than 350.) ${ }^{20}$ In other words, the threat of losing an election prompts the MPs to switch parties if their level of education is not higher than a college degree, and if they attended a less-competitive (lower quality) university.

\section{Electoral Consequences of Party Switching}

The previous section has shown that elected Member of the Parliament switch parties when they face greater election uncertainty. These defectors should have switched parties to enhance their chances of re-election as a member of their new party in the next election. In this section we investigate the consequences of switching parties in terms of candidacy and electoral

\footnotetext{
${ }^{20}$ To give a few examples about the quality variation between universities, the average score of the admitted students to Suleymen Demirel University is 250. Ankara University has a score of 300, and Hacettepe University's average score is 350. Marmara University has a score of 400. ITU, ODTU and Bogazici universities have a score of 450 .
} 
chances of MPs in the subsequent elections by estimating equation (4). Tables 12 and 13 present the results.

In Table 12 the outcome variable in column (1) is Ran for re-election, which measures whether the MP ran as a candidate in the next election. The coefficient of Party Switch in Table 12 is not statistically different from zero, suggesting no difference between switchers and nonswitchers in terms of their propensity for running for re-election.

In columns (2) to (5), the outcome variables are the thresholds that the MP has faced in the next election based on their rank on the party list and the district in which they are nominated. In these regressions, we use the sample of MPs who ran in subsequent elections. The dependent variable in column (2) is Min \% Vote for Guaranteed Re-election. Recall that the value of this variable for each politician is calculated based the number of parties that compete in the election in that district and the number of seats available in the district (see Equation 2). A larger value of this variable implies a higher threshold for being elected. Thus, a lower value of Min \% Vote for Guaranteed Re-election implies more favorable election prospects for the MP. The coefficients of Party Switch are negative and significant in regressions reported in columns (2) and (3). This means that after switching parties, the MPs are nominated in districts and/or on ticket ranking such that they need their new party to receive a smaller share of votes for them to secure re-lection. In other words, conditional on running, MPs who had switched parties are nominated by their new parties at ranks or districts that increased their ex-ante chances of reelection in comparison to the previous election (when they were elected under a different party). ${ }^{21}$

\footnotetext{
${ }^{21}$ Since we can only observe the rank and district of MPs who ran for re-election, samples in columns 2-5 of Table 12 regressions are estimated over the MPs who ran for re-election. To guard against the potentially confounding selection effect, we use the inverse-probability-weighting (IPW) procedure Wooldridge (2002). IPW gives less
} 
The coefficient of Party Switch is about -5 in columns (2) and (3) of Table 12. The interpretation is the following: the advantage gained in the next election (by switching parties between elections) is akin to being nominated as a second-ranked candidate as opposed to being the third-ranked candidate in a district with 19 seats, or equivalent to being nominated as the third-ranked candidate in a district with 13 seats instead of being nominated in a district with 10 seats.

Columns (4) and (5) of Table 12 presents the results where the dependent variable is the Minimum \% of votes needed for re-election probability to be positive (See Equation 3 ). The coefficient of Party Switch is negative and statistically significant, indicating that party switchers are being nominated by their new parties at positions that allow them to be elected by smaller percentage of votes cast for the party. In other words, their new parties treat them favorably by nominating them at ranks that are associated with better chances of winning. These results mean that the MPs decision to switch parties has paid off ex-ante.

The results in Table 12 also show that MPs who were members of the cabinet are more likely to run in the next election (column 1), and at the same time they are nominated at ranks and districts that are highly favorable for their re-election (columns 2-5). On the other hand, those who served the first time as an MP in the previous parliamentary term (Freshman) are less likely run for a second-term, and conditional on running, they are nominated in positions that are less favorable for their re-election prospects.

Those MPs who have obtained a degree abroad are nominated by their parties at more advantageous positions. Specifically, these individuals face $2 \%(1 \%)$ smaller threshold for their

weight to observations from MPs who are more likely to be in the sample (more likely to run for re-election). The weights are the inverse of the predicted probability of running in the re-election (column 1 of Table 12). Results without IPW are almost identical to those presented in Table 12. 
guaranteed re-election (for non-zero re-election probability) compared to those who went to school in Turkey. That is equivalent to about half a rank improvement in their nomination in a district with 10 seats.

In summary, the results of Table 12 reveal that those MPs who switched parties after winning an election, are in fact treated favorably by their new parties and they are listed as candidates in the next election in districts and at party list ranks that are ex-ante more favorable for their election chances in comparison to the treatment they received by their previous party.

\section{Voter Behavior: Do Party Switchers get Re-elected in the Next Election?}

Although party switchers are nominated by their new parties at positions that are more favorable for their re-election chances, ultimately voters decide whether to elect a candidate. We investigate whether party switchers are more likely to get re-elected in the next election by estimating equation (4) using the outcome variable Re-elected. This variable is equal to one if the MP is elected in the subsequent election. The results are presented in Table 13. Column (4) shows that party switchers are more likely to get re-elected, although the magnitude of the impact is small (0.4 percentage points). Columns (2) and (3) show that controlling for Minimum $\%$ Vote for Guaranteed Election, or Minimum \% Vote for Prob(Election)>0, party switching has no direct impact on re-election chances. ${ }^{22}$ The results of Table 12 showed that party-switchers receive preferential treatment by their new (destination) parties in terms of their rank on the party

\footnotetext{
${ }^{22}$ In these regressions, we use inverse probability weighting method. Specifically the weights are the inverse of the predicted probabilities estimated in column 1 of Table 13. We also estimated unweighted regressions. Their results show that there is no statistically significant difference in re-election probabilities of party switchers vs. those who did not switch.
} 
ticket. Together these results imply that the positive impact of party-switching on re-election probability is working through its impact on better treatment by the destination party.

In column (1) of Table 13, the dependent variable is whether the party was successful in the election in gathering at least $10 \%$ of the nation-wide vote. Recall that if party cannot fetch at least $10 \%$ of nation-wide vote, it cannot be represented in the Parliament regardless of the outcome in any particular district. Column (1) shows that party switchers are more likely to switch to smaller parties: those that fail to pass the $10 \%$ vote threshold. Thus, the result of column (1) implies that MPs tend to switch to smaller, less popular parties (being a bigger fish in a smaller pond), and that these parties have a lower chance of staying above the national $10 \%$ vote threshold. Yet, as shown in column (4), despite this, in the end, the MP has a slightly higher probability of getting elected.

The results of Table 13 indicate that party switching MPs have slightly higher chances of re-election. While this finding explains why MPs switch parties, it seems to go against the prediction that voters would reprimand dishonest politicians by not re-electing them. It should be remembered, however, that in this electoral system, voters cast votes for the entire party ticket. In other words, even if voters are uncomfortable with having a politician on their party's ticket who was elected to the Parliament in the previous election from another party, voters may still cast their votes for their party because the utility of their party producing more MPs in the election may outweigh the disutility of electing the dishonest party-switcher.

To shed more light on this issue, we estimate regressions where we analyze the share of votes received by each party in each city in each election as shown by Equation (6). Here, the unit of observation is a city-election-party. We analyze how the vote share of the party changed 
from one election to another and whether this change is impacted by whether or not the party's ticket in that election in that city contained an MP who was transferred from another party.

A party's vote share in each city can be impacted by that party's nation-wide popularity in that election. Therefore, we also control for the nation-wide vote share of the party. In addition, we include an indicator variable to account whether the party was in the government leading to the election. The models also include parliamentary-term fixed-effects, party fixedeffects and city fixed effects.

The results are reported in Table 14. The key variable is MPs Gained, which stands for the number of MPs who switched to the party from another party during the parliamentary term just ended. The results show that if the party's ticket contains an MP who is transferred from another party, then the proportion of votes received by that party in that city goes up by about 2 percentage points. This means that in a median city with 100,000 voters, the party has received 2,000 more votes (in comparison to the previous election) because of the transfer of the MP from another party.

\section{Abandoning Constitutional Checks and Balances and A Potential Explanation of Voter Behavior}

In order to prevent party switching of politicians and the associated moral hazard, article 84 of the Turkish Constitution, adopted in 1982, stipulated sanctions for MPs from changing parties during a Parliamentary term. Specifically, the first paragraph in article 84 laid out the procedure for impeachment of the MPs “ “... who join another party by resigning from their party..." This means that if an MP switches parties, he/she may lose his/her position as an MP 
because the Parliament may decide to vote to expel this MP from the Parliament. In addition, the second paragraph of the article stated that "An MP who resigns from her/his party cannot be nominated in the next election by any party that existed on the day of her/his resignation." However, neither of these clauses proved to be effective. This is because, in order to eliminate the risk of impeachment, the MPs who wanted to switch parties used a procedure, implemented in two steps. First, the MP who wanted to switch to another party formed a brand-new party upon resignation from her/his current party. In the second step, s/he announced the merger of this new party with the destination party that s/he want to switch to. Thus, the MP did not technically join another party directly, and avoided the constitutional sanction. Furthermore, the clauses about party switching were eliminated from the constitution on July $23^{\text {rd }}, 1995$ by a Parliamentary vote just before end of the $19^{\text {th }}$ parliamentary term (December 24,1995$) .{ }^{23}$

That party switching of politicians during a Parliamentary term constitutes moral hazard and that this act is salient would suggest that voters should react negatively both to the act of party switching and to the maneuvers that are implemented to bypass constitutional checks and balances. Instead, as shown above (Tables 13-14), party switchers and their destination parties are not reprimanded by voters. Does this mean that voters are clueless? Acemoğlu, Robinson and Torvik (2013) provide an explanation. They argue that in weakly institutionalized democracies, as in Turkey, checks and balances imposed on politicians can in fact reduce the rents they can extract. But these constraints (in our case, the inability to switch parties for personal benefit) make it cheaper for politicians to be influenced and bribed by the power elite. Thus, voters may tolerate the dismantling of checks and balances, as was done in Turkey, paving the way for politician rent, in order to reduce the influence of the elite on politicians.

${ }^{23}$ The Parliament consisted of 450 seats in 1995. 391 MPs voted (by secret ballot) on a constitutional amendment that eliminates the provision that blocked party switching. 391 (87\%) voted in favor. 


\section{Where do Switchers Switch?}

We have shown that elected Members of the Parliament (MPs) switch parties when they experienced electoral uncertainty (close elections) in the last election, and that a number of other factors, such as age, education, and MP salaries influence the decision to change party allegiance. Thus, opportunistic concerns determine the decision to switch parties. In this subsection we analyze whether and how party-switchers change their political ideology.

We analyze this question by estimating the following regression.

$$
\begin{gathered}
\text { End_Ideology } y_{m p t+1}=\beta \text { Switcher } r_{m p t}+\gamma \text { Begin_Ideology } y_{m p t}+\text { Switcher }_{m p t} \times \\
\text { Begin_Ideology } y_{m p t}+\boldsymbol{X}_{\boldsymbol{m}} \boldsymbol{\Omega}+\omega_{m p t}
\end{gathered}
$$

Begin_Ideologympt is the index of the political ideology of the party from which $\mathrm{MP}_{\mathrm{m}}$ is elected for the Parliamentary term (t). End_Ideology $y_{m p t}$ is the index of the political ideology of party $(m)$ to which $\mathrm{MP}_{\mathrm{m}}$ switched. It signifies the ideology of the party at the end of the Parliamentary term $(t)$. For those MPs who stayed with the same party and did not change parties during a parliamentary term, End_Ideology $y_{m p t}=$ Begin_Ideology $y_{m p t}$. On the other hand, if the MP has switched parties, End_Ideology ${ }_{m p t}$ represents the ideology of the new (destination) party, while Begin_Ideology $y_{m p t}$ stands for the ideology of his original party. Thus (End_Ideology $y_{m p t}-$ Begin_Ideology $\left.y_{m p t}\right)$ is the distance in the ideological outlook of the two parties.

One important issue is how to measure the ideological outlook of political parties. To make the concept operational, we use data on Turkey from World Values Survey (WVS) for the 
years 1990, 1996, 2001, 2007 and $2011 .^{24}$ The participants were asked about the party they support: "If there were a national election tomorrow, for which party on this list would you vote? (If the response is 'I don't know.') Which party appeals to you the most?" They also were asked how they would self-position themselves in the political spectrum from left to right: "In political matters, people talk of 'the left' and 'the right'. Below is a ten-point scale. '1' indicates most left, and ' 10 ' is most right. How would you place your views on this scale, generally speaking?" The Political Scale Index of a party is the average of left-to-right positions of that party's voters. Analysis of data from different years shows that parties' average voter's location on the political spectrum does not vary from year to year.

Figure 3 presents the Political Scale Index of each party. A smaller (larger) value of the index represents more left-of-the center (right-of-the-center) ideology of the party. In the WVS sample, the median voter is located at the index value of 6 . This is demonstrated by the vertical line in Figure 3. The percentages in parentheses are the shares of votes parties received in elections since 1991. The picture is consistent with other researchers' classifications of parties and most people's priors (Carkoglu and Hinich, 2006; Secor, 2001). For example, the social democratic party (CHP), which is known as a left-wing party, has an average rating of 4, while AKP, a right-wing party, has a rating of 7.5.

The results of estimating Equation (7) are displayed in Table 15. The dependent variable is the ideology index of the political party the MP is affiliated with at the end of the Parliamentary term. In column (1), the coefficient of the ideology of the party at the beginning of the term is 1.012. This confirms that if an MP does not switch parties during a parliamentary term (Party Switch=0), then his/her end-of-term party ideology is the same as his beginning-of-

\footnotetext{
${ }^{24}$ http://www.worldvaluessurvey.org/wvs.jsp. World Values Survey is administered to nationally representative samples that range between 1000 and 3400 .
} 
term ideology. On the other hand, for those MPs who switched parties, the direction of the ideological shift depends on the ideology of their original party (beginning of term). More specifically, the impact of party-switching on end-of-term ideology is equal to 3.964-0.634 x (Beginning-of-term Ideology). As an example, if the original party of the MP is center-right with the ideology index of 7, and if the MP switches parties, the change in ideology is expected to be $3.964-0.634 \times(7)=-0.474$. This means that his new (destination) party's ideology index will be 6.526 , indicating a movement of the MP from right to left.

On the other hand, if the MP's original part was of center-left, for example with an index of 5, and if the MP switches parties, the expected change in ideology is 3.964-0.634 x (5)= +0.794 , implying that the new party's level of ideology would be 5.794 .

These results indicate that party switchers do not change parties randomly; rather they tend to switch parties to move towards the median voter. ${ }^{25}$

\section{Conclusion and Discussion}

Citizens who have voted for a political party lose their voice in the political system and the governance of the country if elected politicians defect and switch to another party during a legislative session. This is particularly true in parliamentary systems with proportional representation (which is the most prevalent election system in the world), where voters cast votes for a political party, and not for particular candidates.

We show that opportunistic motives determine the behavior of the elected Members of the Parliament (MPs) in terms of switching parties after winning a general election. We utilize

\footnotetext{
${ }^{25}$ The location of parties on political spectrum has not moved over this time period, with one exception. One of the social democratic parties (CHP) has moved slightly to the right (from 3.5 to 5).
} 
detailed information on personal attributes of more than 2,000 elected MPs and the votes received by each political party in each district and every election in five consecutive Parliamentary elections in Turkey between 1991 and 2011. We exploit a unique feature of the d'Hondt seat allocation formula used in Parliamentary election systems. In this method, based on proportional representation in the presence of multiple political parties, a small shift in the distribution of votes between parties in an election district has an impact on who gets elected from a party ticket. This feature of the d'Hondt method introduces noise to the process of who gets elected to the Parliament from a given district and who loses by a small margin.

We calculate (in different ways) the extent of electoral uncertainty faced by each MP during the election. We find that politicians are more likely to switch parties after an election (despite the fact that they won a seat in the Parliament) if they faced election uncertainty. That is, those MPs who had a narrow victory are more likely to switch parties after the election.

We also find that the tendency to switch parties goes up as it becomes more lucrative to hold the post of MP. A rise in MP salaries -in comparison to the average income of the city from which they are elected- increases the propensity to switch parties. The results also show election uncertainty triggers party switching for younger politicians, but not for older ones. ${ }^{26}$ Importantly, we show that the tendency to switch party affiliation due to election risk is driven by less educated politicians, but the undergraduate college major of the MP, or the graduate-level field of study has no impact on the propensity to switch parties. On the other hand, the increase in the quality (selectiveness) of the university from which the MP has graduated mitigates the impact of electoral uncertainty on party switching.

\footnotetext{
${ }^{26}$ This supports the finding that young Italian mayors act more strategically for re-election and career concerns because they have a longer potential career in front of them (Alesina et al. 2015).
} 
If the MP is a member of the governing party, then his/her probability of switching parties is greater. This is likely because in this case it is a more attractive proposition for him/her to transfer to another party. Such a transfer is more valuable for destination parties (which are in the opposition in the Parliament) as an MP's party switch to the opposition would weaken the government. Supporting this hypothesis, we find that the propensity of an MP to jump ship and transfer to another party is higher if the MP is a member of the governing party, but only if the majority of that party in the Parliament is slim (fewer than 25 seats in the 550-seat Parliament).

It could be the case that less loyal and more opportunistic politicians are placed by the their parties on party-ticket ranks that are associated with more election risk. To address this concern we control for a number of politician attributes that gauge loyalty. For example, we control for whether the MP was elected from the same party in a previous election, whether the MP as appointed as a Cabinet member, and the extent of the effort and visibility of the MP in the Parliament after the election. Importantly, the same results are obtained when we analyze only those politicians who are ranked at the top of the party ticket (those who may be considered as the most loyal by the party), as well those who are ranked $2^{\text {nd }}$ or lower on the ticket. To further account for the potential impact of unobservables, we implemented the procedures suggested by Altonji et al. (2005) and Oster (2014). The results confirmed our findings; and an RDD analysis produced the same conclusion.

In the second part of the paper we analyze the behavior of the MPs and their new parties in the following election. The results show that politicians switch parties to improve their $e x-$ ante re-election probability in the following election. Specifically, we show that the partyswitching politicians are nominated by their new parties in the next election in districts and/or party tickets that are more favorable to their re-election chances. 
In the last section of the paper we analyze the election outcomes in future elections.

Switching parties during a legislative session (between elections) for personal career concerns creates moral hazard because it disenfranchises voters who have voted for the party that MP was elected to represent. If voting is a mechanism through which citizens select politicians who will govern honestly, then voters should oust politicians who abuse the trust of voters. However, we find that party-switching MPs are more likely to get elected in the next election. We also conduct analyses at the party-district-election level and investigate how the vote share of each political party changes between elections in each district. We find that a party's share of votes in the election for an upcoming Parliamentary term goes up (in comparison to the previous election) if that party's ticket in that district contains a politician who has served as an MP for another party in the immediately preceding Parliamentary term. This result suggests that voters of the destination party do not abandon their party to punish a politician who switched to their party after having betrayed his constituents in the original party. Instead, they reward the party that harvested an MP from another party. One should keep in mind, however, that the decision about an MP's re-election is made by the supporters of the destination party (to which the MP has switched) in the next election. It is also important to remember that in this electoral system voters cast votes for the entire party ticket with no split-ticket voting. Thus, we cannot test whether voters enjoy moral hazard imposed on their competitors by the party-switching MP, or they do not appreciate having a dishonest politician on their party's ticket but nevertheless vote for their party because their party's election success is important to them.

Finally, combining our data with data from World Values Survey, we analyze the change in political ideology of the MPs who switch party affiliations. We find that party switching MPs 
do not change parties randomly; rather they tend to switch parties to move towards the median voter. $^{27}$

These results point to forward-looking opportunistic behavior of politicians regarding their strategy to win future elections, and they indicate that politicians switch parties primarily for career concerns and the financial benefits that are associated with longer tenure in the Parliament. The results also signify that competition between political parties continues after the election in the form of gaining seats in the Parliament post- election by transferring politicians who have won elections as representatives of competing parties. This constitutes another dimension of the political agency problem.

\footnotetext{
${ }^{27}$ These results cannot be explained away by the hypothesis of "elected politicians finding a better ideological match for themselves after the election." Under the hypothesis of ideology matching, party switching could occur for any MP, and it would not depend on election uncertainty. Furthermore, if ideology matching were the primary driver of party switching, ex-ante re-election probability would not be impacted by party switching, and party-switchers would not move towards the median voter.
} 
Figure 1

The Effect of Being a Member of Governmental Party on Party Switching

(by the Strength of the Government)

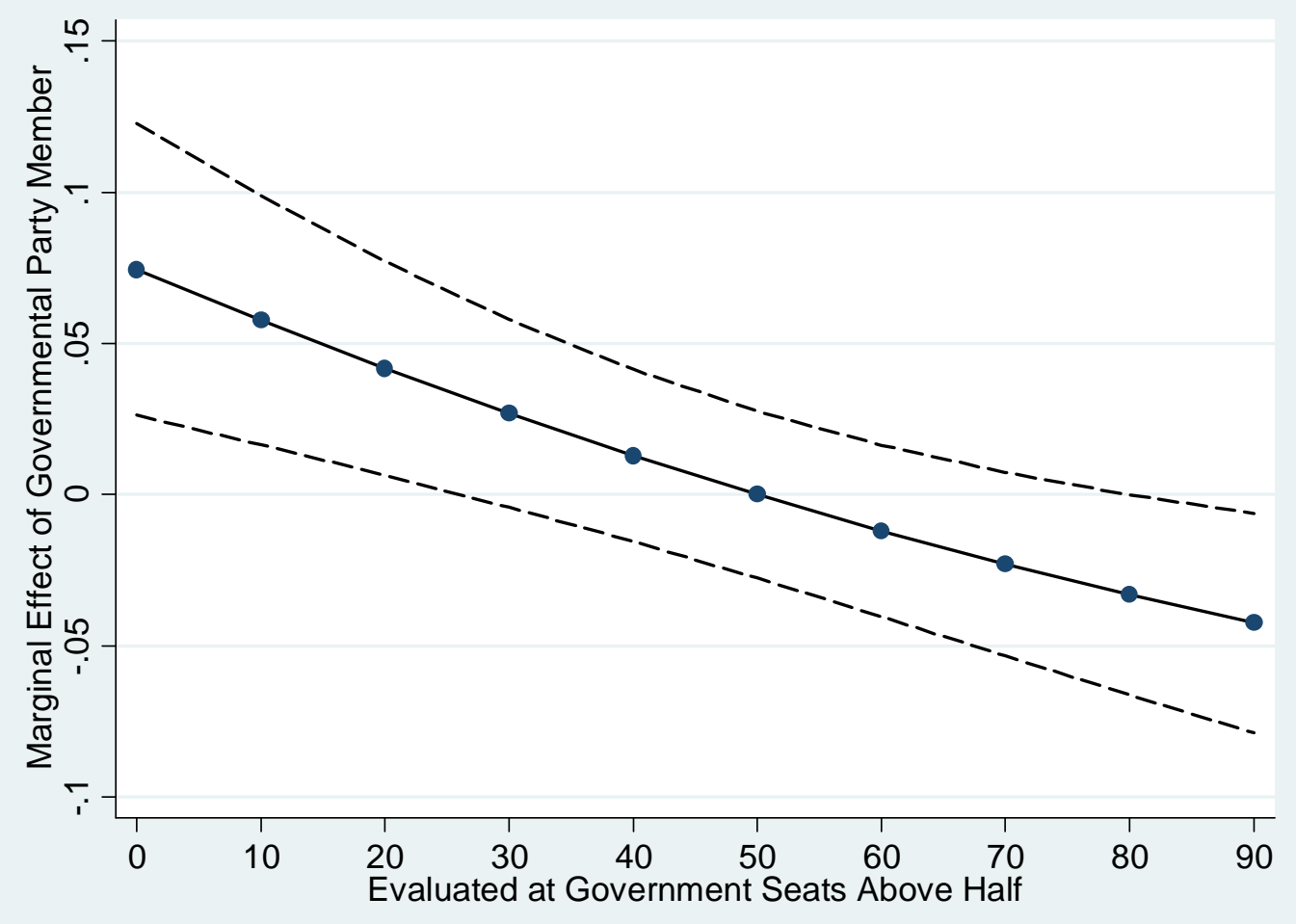




\section{Figure 2 \\ The impact of Electoral Uncertainty on Party Switching Evaluated at various Levels of University Quality (from which the MP graduated)}

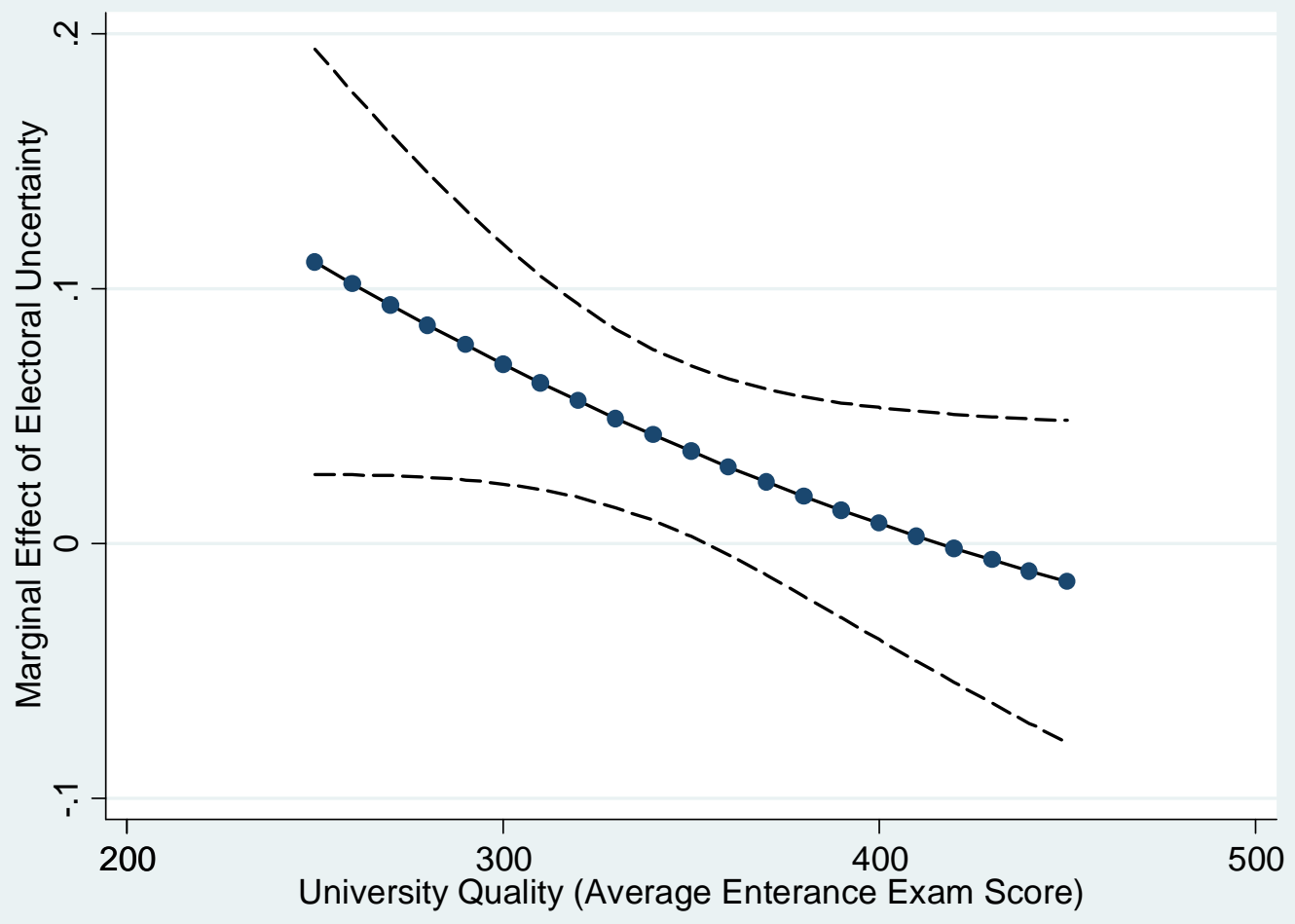

We estimate a probit regression of the form $P($ Party Switch $=1)=\Phi\left(\beta_{1} 2\right.$ nd or Lower $+\beta_{2}$ Quality + $\beta_{3} 2$ nd or Lower $\times$ Quality $+\boldsymbol{X} \boldsymbol{\beta}_{4}+\varepsilon$ ) where Quality is the average university entrance exam score of the MP's university. Greater Quality implies higher student quality in the university. Solid connected line represents the marginal effect of 2 nd or Lower evaluated at various Quality levels. Dashed lines are two standard error confidence intervals. 
Figure 3

Political Parties on Political Spectrum

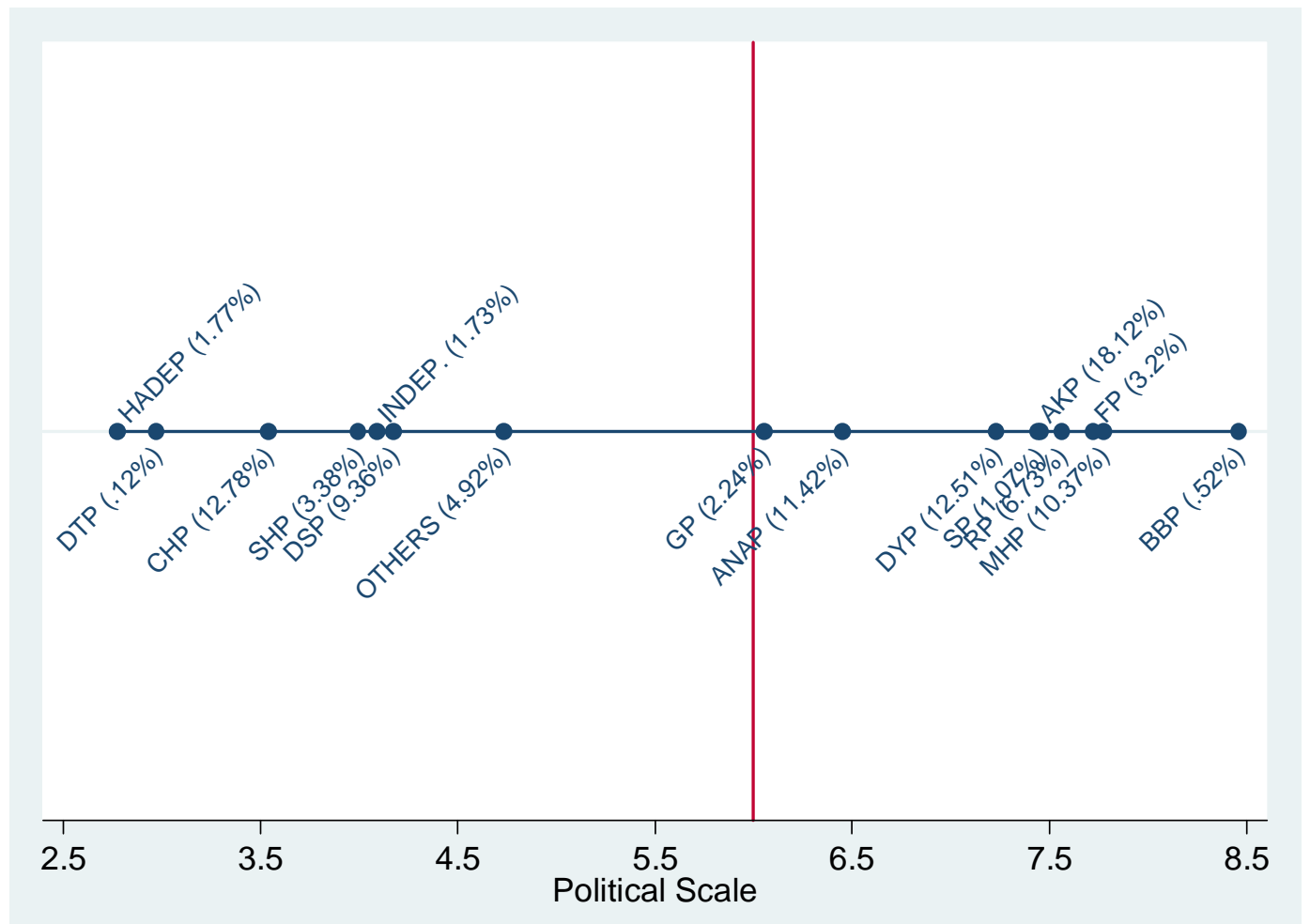

The figure presents the positioning of parties in the political scale that ranges between 1 (most left) and 10 (most right). The value for a party is obtained by averaging the political scale index of the supporters of that party. In parentheses, the vote shares of the party in elections since 1991 are presented. The vertical line represents the median voter (6). 
Table 1

Hypothetical D'Hondt Example of Votes Shares and Seat Allocations

\begin{tabular}{cccccccc}
\hline \multicolumn{7}{c}{ Panel 1 - Vote Distribution 1 } \\
\hline Parties & Votes/1 & Votes/2 & Votes/3 & Votes/4 & Votes/5 & Votes/6 & Votes/7 \\
\hline A & 10.0 & 5.0 & 3.3 & 2.5 & 2.0 & 1.7 & 1.4 \\
B & $\underline{\mathbf{1 3 . 0}}$ & 6.5 & 4.3 & 3.3 & 2.6 & 2.2 & 1.9 \\
C & $\underline{\mathbf{1 9 . 0}}$ & 9.5 & 6.3 & 4.8 & 3.8 & 3.2 & 2.7 \\
D & $\underline{\mathbf{2 5 . 0}}$ & $\underline{\mathbf{1 2 . 5}}$ & 8.3 & 6.3 & 5.0 & 4.2 & 3.6 \\
E & $\underline{\mathbf{3 3 . 0}}$ & $\underline{\mathbf{1 6 . 5}}$ & $\underline{\mathbf{1 1 . 0}}$ & 8.3 & 6.6 & 5.5 & 4.7 \\
\hline
\end{tabular}

Panel 2 - Vote Distribution 2

(2 individuals vote for $\mathrm{A}$ instead of $\mathrm{D})$

\begin{tabular}{cccccccc}
\hline Parties & Votes/1 & Votes/2 & Votes/3 & Votes/4 & Votes/5 & Votes/6 & Votes/7 \\
\hline $\mathrm{A}$ & $\underline{\mathbf{1 2 . 0}}$ & 6.0 & 4.0 & 3.0 & 2.4 & 2.0 & 1.7 \\
$\mathrm{~B}$ & $\underline{\mathbf{1 3 . 0}}$ & 6.5 & 4.3 & 3.3 & 2.6 & 2.2 & 1.9 \\
$\mathrm{C}$ & $\underline{\mathbf{1 9 . 0}}$ & 9.5 & 6.3 & 4.8 & 3.8 & 3.2 & 2.7 \\
$\mathrm{D}$ & $\underline{\mathbf{2 3 . 0}}$ & $\underline{\mathbf{1 1 . 5}}$ & 7.7 & 5.8 & 4.6 & 3.8 & 3.3 \\
$\mathrm{E}$ & $\underline{\mathbf{3 3 . 0}}$ & $\underline{\mathbf{1 6 . 5}}$ & 11.0 & 8.3 & 6.6 & 5.5 & 4.7 \\
\hline
\end{tabular}

Panel 3 - Vote Distribution 3

(4 individuals vote for $\mathrm{A}$ instead of $\mathrm{D}$ )

\begin{tabular}{cccccccc}
\hline Parties & Votes/1 & Votes/2 & Votes/3 & Votes/4 & Votes/5 & Votes/6 & Votes/7 \\
\hline $\mathrm{A}$ & $\underline{\mathbf{1 4 . 0}}$ & 7.0 & 4.7 & 3.5 & 2.8 & 2.3 & 2.0 \\
$\mathrm{~B}$ & $\underline{\mathbf{1 3 . 0}}$ & 6.5 & 4.3 & 3.3 & 2.6 & 2.2 & 1.9 \\
$\mathrm{C}$ & $\underline{\mathbf{1 9 . 0}}$ & 9.5 & 6.3 & 4.8 & 3.8 & 3.2 & 2.7 \\
$\mathrm{D}$ & $\underline{\mathbf{2 1 . 0}}$ & 10.5 & 7.0 & 5.3 & 4.2 & 3.5 & 3.0 \\
$\mathrm{E}$ & $\underline{\mathbf{3 3 . 0}}$ & $\underline{\mathbf{1 6 . 5}}$ & $\underline{\mathbf{1 1 . 0}}$ & 8.3 & 6.6 & 5.5 & 4.7
\end{tabular}

The table presents three examples of how seats in a district with seven seats are allocated to five parties using d'Hondt method. Each panel depicts a separate vote distribution. There are 100 votes cast, so votes $=$ vote shares. The number of votes received by each party is shown in the column (Votes/1) in each panel. d'Hondt method divides each party's votes by consecutive integers up to the number of seats in the district (N). In this example, $\mathrm{N}=7$. The columns "Votes $/ 1 "$, "Votes $/ 2 ", \ldots$, "Votes/7" in the table present the resultant quotients. The parties with the largest $\mathrm{N}$ quotients win the seats. In the examples above, the bold and underlined numbers represent the largest seven quotients. Parties win as many seats as the number of largest quotients they have. For example, under vote distribution 1, parties $\mathrm{B}$ and $\mathrm{C}$ win one seat, $\mathrm{D}$ wins two seats, and $\mathrm{E}$ wins 3 seats. 
Table 2

Hypothetical Example of Vote Shares and Seat Allocations

In a District with 7 Seats and 5 Competing Political Parties

Quotients (Q) of each of the 7 candidates nominated by each of the 5 Parties

Based on the Vote Distribution in the District

\begin{tabular}{cccccccc}
\hline Parties & Votes/1 & Votes/2 & Votes/3 & Votes/4 & Votes/5 & Votes/6 & Votes/7 \\
\hline A & 10.0 & 5.0 & 3.3 & 2.5 & 2.0 & 1.7 & 1.4 \\
B & $\underline{\mathbf{1 3 . 0}}$ & 6.5 & 4.3 & 3.3 & 2.6 & 2.2 & 1.9 \\
C & $\underline{\mathbf{1 9 . 0}}$ & 9.5 & 6.3 & 4.8 & 3.8 & 3.2 & 2.7 \\
D & $\underline{\mathbf{2 5 . 0}}$ & $\underline{\mathbf{1 2 . 5}}$ & 8.3 & 6.3 & 5.0 & 4.2 & 3.6 \\
E & $\underline{\mathbf{3 3 . 0}}$ & $\underline{\mathbf{1 6 . 5}}$ & $\underline{\mathbf{1 1 . 0}}$ & 8.3 & 6.6 & 5.5 & 4.7 \\
\hline
\end{tabular}

Entries highlighted by bold represent the quotients (Q) of each of the 7 winning candidates

Calculation of the Margin of Victory

\begin{tabular}{|c|c|c|c|c|c|}
\hline \multicolumn{6}{|c|}{ Panel 1 - Vote Distribution 1} \\
\hline & $\begin{array}{l}\text { MPs from the } \\
\text { District }\end{array}$ & $\begin{array}{c}\text { Elected } \\
\text { Candidate }\end{array}$ & Q & $\begin{array}{l}\text { Margin of } \\
\text { Victory }\end{array}$ & $\begin{array}{l}\text { Last Candidate } \\
\text { Elected from a } \\
\text { Party's List }\end{array}$ \\
\hline \multirow{8}{*}{ 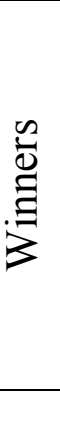 } & 1 & E1 & 33 & $33-10=23$ & 0 \\
\hline & 2 & D1 & 25 & $25-10=15$ & 0 \\
\hline & 3 & $\mathrm{C} 1$ & 19 & $19-10=9$ & 1 \\
\hline & 4 & $\mathrm{E} 2$ & 16.5 & $16.5-10=6.5$ & 0 \\
\hline & 5 & B1 & 13 & $13-10=3$ & 1 \\
\hline & 6 & D2 & 12.5 & $12.5-10=2.5$ & 1 \\
\hline & 7 & E3 & 11 & $11-10=1$ & 1 \\
\hline & 8 & A1 & 10 & & \\
\hline
\end{tabular}

Notes: Q stands for the quotient of each candidate. They are the entries in the cells in top panel of table, pertaining to the candidates with the highest 8 quotients. For example, candidate E1 is the first-ranked candidate on party E's list. Because there are 7 seats, the candidate with the $8^{\text {th }}$ highest quotient is not elected (in this example, this candidate is A1). Such candidates, who barely missed being elected are the Cutoff Candidates, and their quotients are the Cutoff Quotients. Margin of Victory is the difference in quotients between the winning candidates from that district and the quotient of the Cutoff Candidate. 


\section{The Number of MPs and Party Switchers by Parliamentary Term in the Grand National Assembly of Turkey}

\begin{tabular}{cccc}
\hline Term & Starts with election on & MP Observations* & Party Switchers \\
\hline 19 & October.20.1991 & 386 & $70(18.1 \%)$ \\
20 & December.24.1995 & 509 & $75(14.7 \%)$ \\
21 & April.18.1999 & 522 & $91(17.4 \%)$ \\
22 & November.3.2002 & 523 & $29(5.5 \%)$ \\
23 & July.22.2007 & 532 & $30(5.6 \%)$ \\
\hline
\end{tabular}

The table demonstrates the distribution of party switchers across parliamentary terms in our sample. Party switchers are those members of the Parliament (MPs) whose party affiliation at the end of the parliamentary term is different from their affiliation at the start of the term. The $23^{\text {rd }}$ term ended with elections on June 12, 2011. MP observations is the number of MPs whose party affiliations are known both at the beginning and the end of the Parliamentary terms. The circumstances in which this may not be true include the cases where the MP has died during the term, the MP is an independent MP (not affiliated with a party), or resigned from the Parliament during the term. 


\section{Table 4}

Summary Statistics

\begin{tabular}{|c|c|c|c|}
\hline Variable & Description & Mean & Std. Dev. \\
\hline Party Switch & $\begin{array}{l}=1 \text { if MP's initial party affiliation is } \\
\text { different from the end-of-term } \\
\text { affiliation }\end{array}$ & 0.12 & 0.32 \\
\hline Rank & Rank of the MP in their party's list & 2.56 & 2.13 \\
\hline Ranked Second & $\begin{array}{l}=1 \text { if the MP is ranked second in } \\
\text { their party's list }\end{array}$ & 0.24 & 0.43 \\
\hline Ranked Third & $\begin{array}{l}=1 \text { if the MP is ranked third in their } \\
\text { party's list }\end{array}$ & 0.14 & 0.35 \\
\hline Ranked Fourth or Lower & $\begin{array}{l}=1 \text { if the MP is ranked fourth or } \\
\text { lower in their party's list }\end{array}$ & 0.21 & 0.41 \\
\hline $\begin{array}{l}\text { Min \% vote for guaranteed } \\
\text { election }\end{array}$ & $\begin{array}{l}\text { The threshold vote share in the } \\
\text { district over which election of the } \\
\text { candidate is guaranteed }\end{array}$ & 26.70 & 18.25 \\
\hline Min $\%$ vote for election prob $>0$ & $\begin{array}{l}\text { The threshold vote share in the } \\
\text { district over which probability of } \\
\text { election of the candidate is non-zero. }\end{array}$ & 11.93 & 9.17 \\
\hline Margin of Victory (MV) & $\begin{array}{l}\text { Difference in quotient of the MP and } \\
\text { the largest of the quotients of } \\
\text { candidates who are not elected. }\end{array}$ & 8.96 & 10.24 \\
\hline $\begin{array}{l}\text { Elected as the last person on the } \\
\text { ticket }\end{array}$ & $\begin{array}{l}=1 \text { if the MP was the last person } \\
\text { elected from his party's ticket in that } \\
\text { district. }\end{array}$ & 0.42 & 0.49 \\
\hline Member of the government party & $\begin{array}{l}=1 \text { if the MP is elected as a member } \\
\text { of the parties that formed the } \\
\text { government. }\end{array}$ & 0.60 & 0.49 \\
\hline Elected from same party before & $\begin{array}{l}=1 \text { if MP was elected before from his } \\
\text { current party. }\end{array}$ & 0.35 & 0.48 \\
\hline Relative Salary & $\begin{array}{l}\text { Ratio of real salary of the MP to the } \\
\text { per capita income in the district } \\
\text { where MP is elected }\end{array}$ & 1.49 & 0.94 \\
\hline Party's Vote Share & $\begin{array}{l}\text { Share of votes that MP's party } \\
\text { obtained in MP's district }\end{array}$ & 30.14 & 15.24 \\
\hline Seats in district & $\begin{array}{l}\text { Number of seats MP's district is } \\
\text { represented in the parliament }\end{array}$ & 9.65 & 5.97 \\
\hline Cabinet Member & $\begin{array}{l}=1 \text { if } \mathrm{MP} \text { is also a member of the } \\
\text { cabinet }\end{array}$ & 0.12 & 0.32 \\
\hline
\end{tabular}


Table 4 (concluded)

\begin{tabular}{|c|c|c|c|}
\hline Variable & Description & Mean & Std. Dev. \\
\hline Freshman & $\begin{array}{l}=1 \text { if MP has never served in the } \\
\text { parliament in prior terms }\end{array}$ & 0.59 & 0.49 \\
\hline Age $\geq 50$ & $=1$ if $\mathrm{MP}$ is older than 50 & 0.44 & 0.50 \\
\hline Female & $=1$ if MP is female & 0.05 & 0.21 \\
\hline School Abroad & $\begin{array}{l}=1 \text { if MP obtained a degree outside } \\
\text { of Turkey }\end{array}$ & 0.08 & 0.27 \\
\hline $\mathrm{MA} / \mathrm{PhD}$ & $\begin{array}{l}=1 \text { if MP obtained a master's degree } \\
\text { or a doctorate }\end{array}$ & 0.31 & 0.46 \\
\hline Ran for re-election & $\begin{array}{l}=1 \text { if the MP ran for office in the } \\
\text { next election }\end{array}$ & 0.67 & 0.47 \\
\hline $\begin{array}{l}\text { Min \% vote for guaranteed re- } \\
\text { election }\end{array}$ & $\begin{array}{l}\text { The threshold vote share in the } \\
\text { district over which probability of } \\
\text { election of the candidate is non-zero } \\
\text { in the subsequent election. }\end{array}$ & 23.47 & 17.25 \\
\hline Min $\%$ vote for re-election prob $>0$ & $\begin{array}{l}\text { The threshold vote share in the } \\
\text { district over which probability of } \\
\text { election of the candidate is non-zero } \\
\text { in the subsequent election. }\end{array}$ & 9.67 & 7.44 \\
\hline Re-elected & $\begin{array}{l}=1 \text { if MP is re-elected in the next } \\
\text { election. }\end{array}$ & 0.37 & 0.48 \\
\hline$>10 \%$ & $\begin{array}{l}=1 \text { if MP's party obtained at least } \\
10 \% \text { of the votes nationally. }\end{array}$ & 0.71 & 0.45 \\
\hline
\end{tabular}


Table 5

The Effect of Electoral Uncertainty on the Probability of Party Switching

\begin{tabular}{|c|c|c|c|c|c|c|c|c|}
\hline & $(1)$ & $(2)$ & $(3)$ & (4) & $(5)$ & $(6)$ & (7) & $(8)$ \\
\hline Rank & $\begin{array}{l}0.010^{*} \\
(0.005)\end{array}$ & & & & & & & \\
\hline Ranked $2^{\text {nd }}$ or lower & & $\begin{array}{c}0.025 * * \\
(0.011)\end{array}$ & & & & & & \\
\hline Ranked $2^{\text {nd }}$ & & & $\begin{array}{l}0.023 * \\
(0.012)\end{array}$ & $\begin{array}{l}0.023 * \\
(0.012)\end{array}$ & & & & \\
\hline Ranked $3^{\text {rd }}$ & & & & $\begin{array}{l}0.024 * \\
(0.015)\end{array}$ & & & & \\
\hline Ranked $3^{\text {rd }}$ or lower & & & $\begin{array}{l}0.029 * * \\
(0.013)\end{array}$ & & & & & \\
\hline Ranked $4^{\text {th }}$ or lower & & & & $\begin{array}{c}0.035 * * \\
(0.018)\end{array}$ & & & & \\
\hline $\begin{array}{l}\text { Min } \% \text { vote for } \\
\text { guaranteed election }\end{array}$ & & & & & $\begin{array}{l}0.001 * * \\
(0.000)\end{array}$ & & & \\
\hline $\begin{array}{l}\text { Min } \% \text { vote for } \\
\text { election prob }>0\end{array}$ & & & & & & $\begin{array}{l}0.001 * \\
(0.001)\end{array}$ & & \\
\hline Margin of victory (MV) & & & & & & & $\begin{array}{l}-0.001 * \\
(0.001)\end{array}$ & \\
\hline $\begin{array}{l}\text { Elected as the last person } \\
\text { on the ticket }\end{array}$ & & & & & & & & $\begin{array}{l}0.020 * \\
(0.010)\end{array}$ \\
\hline $\begin{array}{l}\text { Member of the } \\
\text { government party }\end{array}$ & $\begin{array}{c}0.074 * * * \\
(0.017)\end{array}$ & $\begin{array}{c}0.070 * * * \\
(0.016)\end{array}$ & $\begin{array}{c}0.070 * * * \\
(0.016)\end{array}$ & $\begin{array}{c}0.070 * * * \\
(0.016)\end{array}$ & $\begin{array}{c}0.071 * * * \\
(0.016)\end{array}$ & $\begin{array}{c}0.072 * * * \\
(0.016)\end{array}$ & $\begin{array}{c}0.078 * * * \\
(0.016)\end{array}$ & $\begin{array}{c}0.074 * * * \\
(0.016)\end{array}$ \\
\hline $\begin{array}{l}\text { Elected from } \\
\text { same party before }\end{array}$ & $\begin{array}{c}-0.098 * * * \\
(0.021)\end{array}$ & $\begin{array}{c}-0.092 * * * \\
(0.020)\end{array}$ & $\begin{array}{c}-0.092 * * * \\
(0.020)\end{array}$ & $\begin{array}{c}-0.092 * * * \\
(0.020)\end{array}$ & $\begin{array}{c}-0.093 * * * \\
(0.020)\end{array}$ & $\begin{array}{c}-0.094 * * * \\
(0.020)\end{array}$ & $\begin{array}{c}-0.089 * * * \\
(0.020)\end{array}$ & $\begin{array}{c}-0.093 * * * \\
(0.020)\end{array}$ \\
\hline
\end{tabular}




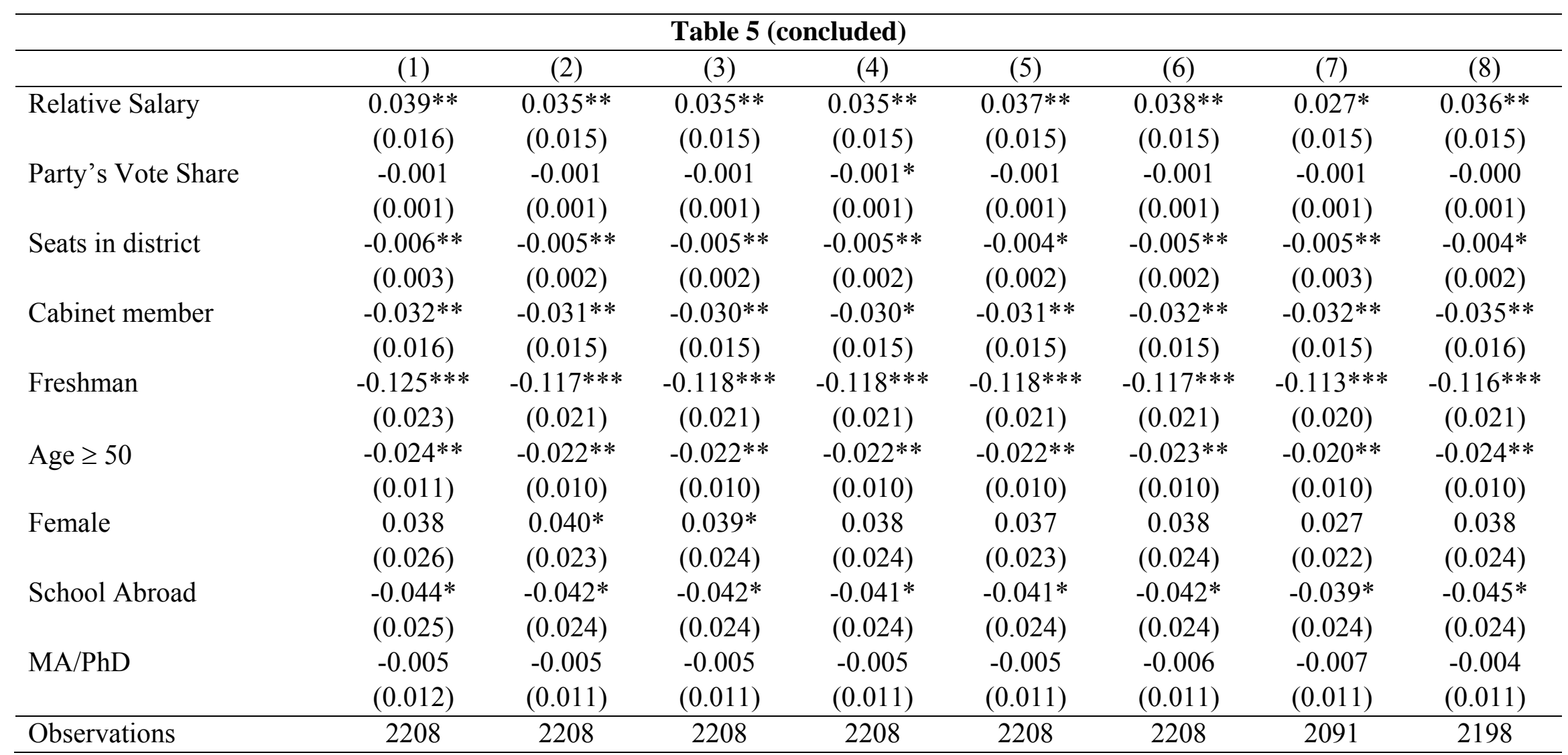

Notes: The outcome variable is Party Switch which takes the value of one if the MP's party affiliation at the beginning of the parliamentary term is different from their affiliation at the end of the term. Table presents the marginal effects obtained from probit regressions. In addition to the variables listed, regressions include indicators for MPs' party affiliation at the beginning of the parliamentary term, city fixed effects and parliamentary term dummies. Robust standard errors clustered at the MP level are reported in parentheses. $* * *$, and $* * *$ indicate statistical significance at $10 \%, 5 \%$ and $1 \%$, respectively. 


\section{Table 6}

Effect of Electoral Uncertainty on Party Switching in Very Tight Elections

\begin{tabular}{|c|c|c|c|c|c|c|}
\hline & \multicolumn{3}{|c|}{ Margin of Victory $\leq 5$} & \multicolumn{3}{|c|}{ Margin of Victory $\leq 3$} \\
\hline & (1) & (2) & (3) & (4) & (5) & (6) \\
\hline Ranked 2nd or lower & $\begin{array}{c}0.075^{* *} \\
(0.032)\end{array}$ & & & $\begin{array}{c}0.109 * * \\
(0.047)\end{array}$ & & \\
\hline $2^{\text {nd }}$ Ranked & & $\begin{array}{c}0.074 * * \\
(0.032)\end{array}$ & $\begin{array}{c}0.074^{* *} \\
(0.033)\end{array}$ & & $\begin{array}{c}0.109 * * \\
(0.047)\end{array}$ & $\begin{array}{c}0.106^{* *} \\
(0.048)\end{array}$ \\
\hline $3^{\text {rd }}$ Ranked & & & $\begin{array}{c}0.078^{* *} \\
(0.036)\end{array}$ & & & $\begin{array}{c}0.109 * * \\
(0.051)\end{array}$ \\
\hline Ranked $3^{\text {rd }}$ or lower & & $\begin{array}{c}0.078^{* *} \\
(0.036)\end{array}$ & & & $\begin{array}{c}0.110^{* *} \\
(0.051)\end{array}$ & \\
\hline Ranked $4^{\text {th }}$ or lower & & & $\begin{array}{l}0.076^{*} \\
(0.045)\end{array}$ & & & $\begin{array}{c}0.093 \\
(0.060) \\
\end{array}$ \\
\hline
\end{tabular}

Notes: The outcome variable is Party Switch which takes the value of one if the MP's party affiliation at the beginning of the parliamentary term is different from their affiliation at the end of the term. Table presents the marginal effects obtained from probit regressions. Columns 1 to 3 (4 to 6) are obtained from the sample where MPs are elected with a quotient margin less than 5\% (3\%). Regressions include the whole set of control variables as in Table 5. Robust standard errors clustered at the MP level are reported in parentheses. *, **, and *** indicate statistical significance at $10 \%, 5 \%$ and $1 \%$, respectively. 


\section{Table 7}

Effect of Electoral Uncertainty on Party Switching Alternative Specifications

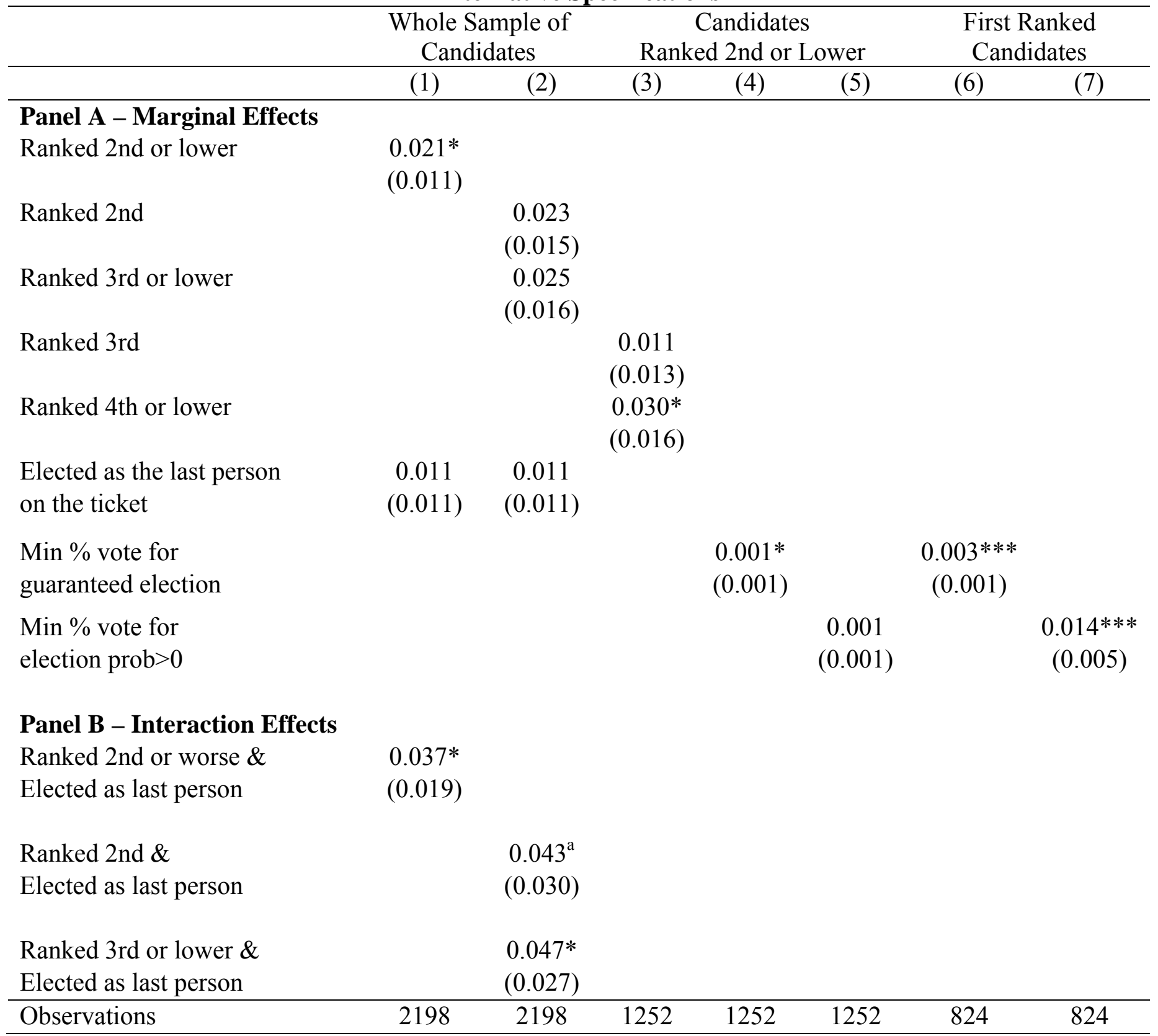

Notes: The outcome variable is Party Switch which takes the value of one if the MP's party affiliation at the beginning of the parliamentary term is different from their affiliation at the end of the term. Panel A presents the marginal effects obtained from probit regressions. Panel B shows the interaction effects of the rank variables and Elected as last person. The interaction effects are the difference of marginal effects of the rank variables at Elected as last person $=1$ and $=0$. Estimates in columns 1 and 2 are obtained from using the whole sample. Results in columns 3-5 (6-7) pertain to the sample of MPs whose rank is $2^{\text {nd }}$ or lower (who are first ranked). The whole set of control variables as in Table 5 are included in the regressions. Robust standard errors clustered at the MP level are reported in parentheses. ${ }^{*}, * *$, and $* * *$ indicate statistical significance at $10 \%, 5 \%$ and $1 \%$, respectively. ${ }^{\mathrm{a}} \mathrm{p}$-value $=0.15$ 
Table 8

The Effect of Electoral Uncertainty on the Probability of Party Switching

\section{Conditional on MP's Effort}

\begin{tabular}{|c|c|c|c|c|c|c|c|c|}
\hline & (1) & (2) & (3) & (4) & (5) & (6) & (7) & (8) \\
\hline Rank & $\begin{array}{l}0.009 * \\
(0.005)\end{array}$ & & & & & & & \\
\hline Ranked $2^{\text {nd }}$ or lower & & $\begin{array}{l}0.024 * * \\
(0.011)\end{array}$ & & & & & & \\
\hline Ranked $2^{\text {nd }}$ & & & $\begin{array}{l}0.022 * \\
(0.012)\end{array}$ & $\begin{array}{l}0.022 * \\
(0.012)\end{array}$ & & & & \\
\hline Ranked $3^{\text {rd }}$ & & & & $\begin{array}{c}0.023 \\
(0.014)\end{array}$ & & & & \\
\hline Ranked $3^{\text {rd }}$ or lower & & & $\begin{array}{c}0.027 * * \\
(0.013)\end{array}$ & & & & & \\
\hline Ranked $4^{\text {th }}$ or lower & & & & $\begin{array}{l}0.033^{*} \\
(0.017)\end{array}$ & & & & \\
\hline $\begin{array}{l}\text { Min } \% \text { vote for } \\
\text { guaranteed election }\end{array}$ & & & & & $\begin{array}{l}0.001 * * \\
(0.000)\end{array}$ & & & \\
\hline $\begin{array}{l}\text { Min } \% \text { vote for } \\
\text { election prob }>0\end{array}$ & & & & & & $\begin{array}{l}0.001 * \\
(0.001)\end{array}$ & & \\
\hline Margin of victory (MV) & & & & & & & $\begin{array}{l}-0.001 * \\
(0.001)\end{array}$ & \\
\hline $\begin{array}{l}\text { Elected as the last person } \\
\text { on the ticket }\end{array}$ & & & & & & & & $\begin{array}{l}0.018 * \\
(0.010)\end{array}$ \\
\hline Effort & $\begin{array}{l}0.013^{*} \\
(0.008)\end{array}$ & $\begin{array}{c}0.013 \\
(0.008)\end{array}$ & $\begin{array}{c}0.013 \\
(0.008)\end{array}$ & $\begin{array}{c}0.013 \\
(0.008)\end{array}$ & $\begin{array}{c}0.013 \\
(0.008)\end{array}$ & $\begin{array}{c}0.013 \\
(0.008)\end{array}$ & $\begin{array}{l}0.014^{*} \\
(0.008)\end{array}$ & $\begin{array}{c}0.013 \\
(0.008)\end{array}$ \\
\hline $\begin{array}{l}\text { Member of the } \\
\text { government party }\end{array}$ & $\begin{array}{c}0.075 * * * \\
(0.017)\end{array}$ & $\begin{array}{c}0.071 * * * \\
(0.016)\end{array}$ & $\begin{array}{c}0.071 * * * \\
(0.016)\end{array}$ & $\begin{array}{c}0.071 * * * \\
(0.016)\end{array}$ & $\begin{array}{c}0.072 * * * \\
(0.016)\end{array}$ & $\begin{array}{c}0.073 * * * \\
(0.016)\end{array}$ & $\begin{array}{c}0.079 * * * \\
(0.016)\end{array}$ & $\begin{array}{c}0.074 * * * \\
(0.016)\end{array}$ \\
\hline
\end{tabular}




\begin{tabular}{|c|c|c|c|c|c|c|c|c|}
\hline \multicolumn{9}{|c|}{ Table 8 (concluded) } \\
\hline & (1) & (2) & (3) & (4) & (5) & (6) & (7) & (8) \\
\hline Elected from & $-0.097 * * *$ & $-0.091 * * *$ & $-0.091 * * *$ & $-0.091 * * *$ & $-0.092 * * *$ & $-0.092 * * *$ & $-0.087 * * *$ & $-0.091 * * *$ \\
\hline same party before & $(0.022)$ & $(0.020)$ & $(0.020)$ & $(0.020)$ & $(0.020)$ & $(0.020)$ & $(0.020)$ & $(0.020)$ \\
\hline \multirow[t]{2}{*}{ Relative Salary } & $0.039 * *$ & $0.035 * *$ & $0.035 * *$ & $0.035 * *$ & $0.037 * *$ & $0.037 * *$ & $0.027 *$ & $0.036^{* *}$ \\
\hline & $(0.016)$ & $(0.015)$ & $(0.015)$ & $(0.015)$ & $(0.015)$ & $(0.015)$ & $(0.015)$ & $(0.015)$ \\
\hline \multirow[t]{2}{*}{ Party’s Vote Share } & -0.001 & -0.001 & -0.001 & -0.001 & -0.001 & -0.001 & -0.000 & -0.000 \\
\hline & $(0.001)$ & $(0.001)$ & $(0.001)$ & $(0.001)$ & $(0.001)$ & $(0.001)$ & $(0.001)$ & $(0.001)$ \\
\hline \multirow[t]{2}{*}{ Seats in district } & $-0.006 * *$ & $-0.005 * *$ & $-0.005 * *$ & $-0.005 * *$ & $-0.004 *$ & $-0.005 * *$ & $-0.005 * *$ & $-0.004^{*}$ \\
\hline & $(0.003)$ & $(0.002)$ & $(0.002)$ & $(0.002)$ & $(0.002)$ & $(0.002)$ & $(0.003)$ & $(0.002)$ \\
\hline \multirow[t]{2}{*}{ Cabinet member } & $-0.032 * *$ & $-0.031 * *$ & $-0.030 * *$ & $-0.030 * *$ & $-0.031 * *$ & $-0.032 * *$ & $-0.032 * *$ & $-0.034 * *$ \\
\hline & $(0.016)$ & $(0.015)$ & $(0.015)$ & $(0.015)$ & $(0.015)$ & $(0.015)$ & $(0.015)$ & $(0.015)$ \\
\hline \multirow[t]{2}{*}{ Freshman } & $-0.124 * * *$ & $-0.116 * * *$ & $-0.117 * * *$ & $-0.117 * * *$ & $-0.117 * * *$ & $-0.116 * * *$ & $-0.112 * * *$ & $-0.115 * * *$ \\
\hline & $(0.023)$ & $(0.021)$ & $(0.021)$ & $(0.021)$ & $(0.021)$ & $(0.021)$ & $(0.020)$ & $(0.021)$ \\
\hline \multirow[t]{2}{*}{ Age $\geq 50$} & $-0.024 * *$ & $-0.022 * *$ & $-0.022 * *$ & $-0.022 * *$ & $-0.022 * *$ & $-0.023 * *$ & $-0.020 * *$ & $-0.024 * *$ \\
\hline & $(0.011)$ & $(0.010)$ & $(0.010)$ & $(0.010)$ & $(0.010)$ & $(0.010)$ & $(0.010)$ & $(0.010)$ \\
\hline \multirow[t]{2}{*}{ Female } & 0.040 & $0.041 *$ & $0.040 *$ & $0.039 *$ & $0.039 *$ & $0.039 *$ & 0.028 & 0.039 \\
\hline & $(0.025)$ & $(0.023)$ & $(0.024)$ & $(0.023)$ & $(0.023)$ & $(0.023)$ & $(0.022)$ & $(0.024)$ \\
\hline \multirow[t]{2}{*}{ School Abroad } & $-0.048 * *$ & $-0.046 * *$ & $-0.046 * *$ & $-0.046 * *$ & $-0.045 * *$ & $-0.046 * *$ & $-0.044^{*}$ & $-0.049 * *$ \\
\hline & $(0.024)$ & $(0.023)$ & $(0.023)$ & $(0.023)$ & $(0.023)$ & $(0.023)$ & $(0.023)$ & $(0.023)$ \\
\hline \multirow[t]{2}{*}{$\mathrm{MA} / \mathrm{PhD}$} & -0.005 & -0.005 & -0.005 & -0.004 & -0.005 & -0.005 & -0.006 & -0.004 \\
\hline & $(0.012)$ & $(0.011)$ & $(0.011)$ & $(0.011)$ & $(0.011)$ & $(0.011)$ & $(0.011)$ & $(0.011)$ \\
\hline Observations & 2207 & 2207 & 2207 & 2207 & 2207 & 2207 & 2090 & 2197 \\
\hline $\begin{array}{l}\text { Notes: The outcome va } \\
\text { their affiliation at the e } \\
\text { the MP (such as speech } \\
\text { Table } 5 \text { are included in } \\
\text { significance at } 10 \%, 5^{\circ}\end{array}$ & $\begin{array}{l}\text { ty Switch } \\
\text { m. Table pr } \\
\text { ind oral que } \\
\text { ons. Robus }\end{array}$ & dard errors & one ift & nonts & o $E f$ & 010 & ntarytar & $\begin{array}{l}\text { ferent from } \\
\text { tivities of } \\
\text { as in in }\end{array}$ \\
\hline
\end{tabular}




\section{Table 9}

The Effect of Electoral Uncertainty on the Probability of Party Switching by MP's Age

\begin{tabular}{|c|c|c|c|c|c|}
\hline & \multicolumn{3}{|c|}{ Whole Sample } & \multirow{2}{*}{$\begin{array}{c}\text { Age }<50 \\
(4)\end{array}$} & \multirow{2}{*}{$\begin{array}{c}\text { Age } \geq 50 \\
(5)\end{array}$} \\
\hline & (1) & (2) & (3) & & \\
\hline Ranked 2nd or lower & $\begin{array}{l}0.025^{* *} \\
(0.011)\end{array}$ & $\begin{array}{l}0.023^{* *} \\
(0.011)\end{array}$ & $\begin{array}{c}0.024 * * \\
(0.011)\end{array}$ & $\begin{array}{c}0.039^{* *} \\
(0.017)\end{array}$ & $\begin{array}{l}-0.001 \\
(0.016)\end{array}$ \\
\hline Age & & $\begin{array}{c}-0.002^{* * *} \\
(0.001)\end{array}$ & & & \\
\hline Age 40-49 & & & $\begin{array}{c}-0.045^{* * *} \\
(0.013)\end{array}$ & & \\
\hline Age $50-59$ & & & $\begin{array}{c}-0.054^{* * *} \\
(0.014)\end{array}$ & & \\
\hline Age $\geq 60$ & & & $\begin{array}{c}-0.072^{* * *} \\
(0.020)\end{array}$ & & \\
\hline Age $\geq 50$ & $\begin{array}{c}-0.022^{* *} \\
(0.010)\end{array}$ & & & & \\
\hline Member of Gov't Party & $\begin{array}{c}0.070^{* * *} \\
(0.016)\end{array}$ & $\begin{array}{c}0.070^{* * *} \\
(0.016)\end{array}$ & $\begin{array}{c}0.069^{* * *} \\
(0.016)\end{array}$ & $\begin{array}{c}0.072 * * * \\
(0.023)\end{array}$ & $\begin{array}{c}0.077 * * * \\
(0.027)\end{array}$ \\
\hline $\begin{array}{l}\text { Elected from same } \\
\text { party before }\end{array}$ & $\begin{array}{c}-0.092 * * * \\
(0.020)\end{array}$ & $\begin{array}{c}-0.092^{* * *} \\
(0.020)\end{array}$ & $\begin{array}{c}-0.092^{* * *} \\
(0.019)\end{array}$ & $\begin{array}{c}-0.118^{* * *} \\
(0.040)\end{array}$ & $\begin{array}{c}-0.064^{* *} \\
(0.026)\end{array}$ \\
\hline Relative salary & $\begin{array}{l}0.035^{* *} \\
(0.015)\end{array}$ & $\begin{array}{l}0.035^{* *} \\
(0.015)\end{array}$ & $\begin{array}{l}0.035^{* *} \\
(0.015)\end{array}$ & $\begin{array}{c}0.062^{* * * *} \\
(0.023)\end{array}$ & $\begin{array}{c}0.007 \\
(0.022)\end{array}$ \\
\hline Party's Vote Share & $\begin{array}{l}-0.001 \\
(0.001)\end{array}$ & $\begin{array}{l}-0.001 \\
(0.001)\end{array}$ & $\begin{array}{l}-0.001 \\
(0.001)\end{array}$ & $\begin{array}{l}-0.001^{*} \\
(0.001)\end{array}$ & $\begin{array}{l}0.000 \\
(0.001)\end{array}$ \\
\hline Seats in district & $\begin{array}{c}-0.005^{* *} \\
(0.002)\end{array}$ & $\begin{array}{c}-0.005^{* *} \\
(0.002)\end{array}$ & $\begin{array}{c}-0.005^{* *} \\
(0.002)\end{array}$ & $\begin{array}{c}-0.010^{* * *} \\
(0.003)\end{array}$ & $\begin{array}{l}-0.003 \\
(0.003)\end{array}$ \\
\hline Cabinet member & $\begin{array}{c}-0.031 * * \\
(0.015)\end{array}$ & $\begin{array}{l}-0.029^{*} \\
(0.015)\end{array}$ & $\begin{array}{l}-0.029^{*} \\
(0.015)\end{array}$ & $\begin{array}{c}-0.055^{* *} \\
(0.025)\end{array}$ & $\begin{array}{l}-0.026 \\
(0.020)\end{array}$ \\
\hline Freshman & $\begin{array}{c}-0.117 * * * \\
(0.021)\end{array}$ & $\begin{array}{c}-0.122^{* * *} \\
(0.020)\end{array}$ & $\begin{array}{c}-0.121 * * * \\
(0.020)\end{array}$ & $\begin{array}{c}-0.154 * * * \\
(0.040)\end{array}$ & $\begin{array}{c}-0.083^{* * *} \\
(0.025)\end{array}$ \\
\hline Female & $\begin{array}{l}0.040^{*} \\
(0.023)\end{array}$ & $\begin{array}{c}0.034 \\
(0.023)\end{array}$ & $\begin{array}{c}0.032 \\
(0.023)\end{array}$ & $\begin{array}{c}0.095 * * * \\
(0.036)\end{array}$ & $\begin{array}{l}-0.021 \\
(0.030)\end{array}$ \\
\hline School Abroad & $\begin{array}{l}-0.042 * \\
(0.024)\end{array}$ & $\begin{array}{l}-0.040^{*} \\
(0.024)\end{array}$ & $\begin{array}{l}-0.043 * \\
(0.024)\end{array}$ & $\begin{array}{l}-0.045 \\
(0.044)\end{array}$ & $\begin{array}{l}-0.049^{*} \\
(0.027)\end{array}$ \\
\hline $\mathrm{MA} / \mathrm{PhD}$ & $\begin{array}{l}-0.005 \\
(0.011)\end{array}$ & $\begin{array}{l}-0.003 \\
(0.011)\end{array}$ & $\begin{array}{l}-0.003 \\
(0.011)\end{array}$ & $\begin{array}{l}-0.034^{*} \\
(0.018)\end{array}$ & $\begin{array}{c}0.025 \\
(0.016)\end{array}$ \\
\hline Observations & 2208 & 2208 & 2208 & 1185 & 786 \\
\hline
\end{tabular}

Notes: The outcome variable is Party Switch which takes the value of one if the MP's party affiliation at the beginning of the parliamentary term is different from their affiliation at the end of the term. Table presents the marginal effects obtained from probit regressions. Columns 1 to 3 present results obtained from the whole sample. The results in columns 4 and 5 pertain to MPs who age younger than 50 years old and older than 50 years old, respectively. The whole set of control variables are included in the regressions (as in Table 5). Robust standard errors clustered at the MP level are reported in parentheses. *, **, and *** indicate statistical significance at $10 \%$, $5 \%$ and $1 \%$, respectively. 
Table 10

The Effect of Electoral Uncertainty on the Probability of Party Switching by MP's Education

\begin{tabular}{|c|c|c|c|c|}
\hline & \multicolumn{2}{|c|}{ MPs with MA or PhD } & \multicolumn{2}{|c|}{$\begin{array}{c}\text { MPs without MA or } \\
\text { PhD }\end{array}$} \\
\hline & (1) & (2) & (3) & (4) \\
\hline Ranked 2nd or lower & $\begin{array}{c}0.014 \\
(0.024)\end{array}$ & & $\begin{array}{l}0.031 * * \\
(0.015)\end{array}$ & \\
\hline Margins of Victory (MV) & & $\begin{array}{l}-0.000 \\
(0.002)\end{array}$ & & $\begin{array}{c}-0.002 * * \\
(0.001)\end{array}$ \\
\hline Member of Gov't Party & $\begin{array}{c}0.043 \\
(0.032)\end{array}$ & $\begin{array}{c}0.050 \\
(0.031)\end{array}$ & $\begin{array}{c}0.090 * * * \\
(0.021)\end{array}$ & $\begin{array}{c}0.100 * * * \\
(0.023)\end{array}$ \\
\hline $\begin{array}{l}\text { Elected from same } \\
\text { party before }\end{array}$ & $\begin{array}{l}-0.075 \\
(0.048)\end{array}$ & $\begin{array}{l}-0.078 \\
(0.051)\end{array}$ & $\begin{array}{c}-0.105 * * * \\
(0.024)\end{array}$ & $\begin{array}{c}-0.102 * * * \\
(0.024)\end{array}$ \\
\hline Relative salary & $\begin{array}{l}0.113 * \\
(0.066)\end{array}$ & $\begin{array}{c}0.072 \\
(0.074)\end{array}$ & $\begin{array}{c}0.041 * * \\
(0.018)\end{array}$ & $\begin{array}{l}0.034 * \\
(0.019)\end{array}$ \\
\hline Party's Vote Share & $\begin{array}{c}0.000 \\
(0.001)\end{array}$ & $\begin{array}{c}0.001 \\
(0.001)\end{array}$ & $\begin{array}{l}-0.001 * \\
(0.001)\end{array}$ & $\begin{array}{l}-0.001 \\
(0.001)\end{array}$ \\
\hline Seats in district & $\begin{array}{l}-0.002 \\
(0.004)\end{array}$ & $\begin{array}{l}-0.004 \\
(0.005)\end{array}$ & $\begin{array}{c}-0.008 * * * \\
(0.003)\end{array}$ & $\begin{array}{c}-0.007 * * \\
(0.003)\end{array}$ \\
\hline Cabinet member & $\begin{array}{c}-0.084 * * * \\
(0.033)\end{array}$ & $\begin{array}{c}-0.081 * * * \\
(0.031)\end{array}$ & $\begin{array}{l}-0.014 \\
(0.019)\end{array}$ & $\begin{array}{l}-0.014 \\
(0.019)\end{array}$ \\
\hline Freshman & $\begin{array}{l}-0.082 * \\
(0.047)\end{array}$ & $\begin{array}{l}-0.086 * \\
(0.049)\end{array}$ & $\begin{array}{c}-0.142 * * * \\
(0.025)\end{array}$ & $\begin{array}{c}-0.140 * * * \\
(0.025)\end{array}$ \\
\hline Age $\geq 50$ & $\begin{array}{c}0.018 \\
(0.021)\end{array}$ & $\begin{array}{c}0.019 \\
(0.021)\end{array}$ & $\begin{array}{c}-0.046 * * * \\
(0.013)\end{array}$ & $\begin{array}{c}-0.044 * * * \\
(0.013)\end{array}$ \\
\hline Female & $\begin{array}{l}-0.044 \\
(0.037)\end{array}$ & $\begin{array}{l}-0.050 \\
(0.036)\end{array}$ & $\begin{array}{l}0.069 * * \\
(0.032)\end{array}$ & $\begin{array}{l}0.051 * \\
(0.031)\end{array}$ \\
\hline School Abroad & $\begin{array}{l}-0.032 \\
(0.026) \\
\end{array}$ & $\begin{array}{l}-0.031 \\
(0.025)\end{array}$ & & \\
\hline Observations & 462 & 437 & 1492 & 1411 \\
\hline
\end{tabular}

Notes: The outcome variable is Party Switch which takes the value of one if the MP's party affiliation at the beginning of the parliamentary term is different from their affiliation at the end of the term. Table presents the marginal effects obtained from probit regressions. Columns 1 to 2 present results obtained from the sample of MPs who have graduate degrees. The results in columns 3 and 4 pertain to MPs who have college degrees or less. The whole set of control variables are included in the regressions (as in Table 5). Robust standard errors clustered at the MP level are reported in parentheses. ${ }^{*},{ }^{*}$, and $* * *$ indicate statistical significance at $10 \%, 5 \%$ and $1 \%$, respectively. 
Table 11

The Effect of Electoral Uncertainty on the Probability of Party Switching by MP's Education (Conditioning on MP's Area of Study)

\begin{tabular}{|c|c|c|c|c|c|c|}
\hline & \multicolumn{2}{|c|}{ Whole Sample } & \multicolumn{2}{|c|}{ MPs with MA or PhD } & \multicolumn{2}{|c|}{ MPs without MA or $\mathrm{PhD}$} \\
\hline & (1) & (2) & (3) & (4) & (5) & (6) \\
\hline \multirow[t]{2}{*}{ Ranked $2^{\text {nd }}$ or lower } & $0.024 * *$ & & 0.013 & & $0.031 * *$ & \\
\hline & $(0.011)$ & & $(0.023)$ & & $(0.015)$ & \\
\hline \multirow[t]{2}{*}{ Margins of Victory (MV) } & & $-0.001 *$ & & -0.000 & & $-0.002 * *$ \\
\hline & & $(0.001)$ & & $(0.002)$ & & $(0.001)$ \\
\hline \multirow[t]{2}{*}{ Member of Gov't Party } & $0.069 * * *$ & $0.078 * * *$ & 0.045 & 0.051 & $0.090 * * *$ & $0.099 * * *$ \\
\hline & $(0.016)$ & $(0.016)$ & $(0.031)$ & $(0.032)$ & $(0.021)$ & $(0.023)$ \\
\hline \multirow{2}{*}{$\begin{array}{l}\text { Elected from same } \\
\text { party before }\end{array}$} & $-0.090 * * *$ & $-0.088 * * *$ & -0.064 & -0.070 & $-0.104 * * *$ & $-0.101 * * *$ \\
\hline & $(0.020)$ & $(0.020)$ & $(0.046)$ & $(0.049)$ & $(0.024)$ & $(0.024)$ \\
\hline \multirow[t]{2}{*}{ Relative salary } & $0.035 * *$ & $0.026^{*}$ & $0.110^{*}$ & 0.076 & $0.041 * *$ & $0.034^{*}$ \\
\hline & $(0.015)$ & $(0.015)$ & $(0.062)$ & $(0.073)$ & $(0.018)$ & $(0.019)$ \\
\hline \multirow[t]{2}{*}{ Party's Vote Share } & -0.001 & -0.001 & 0.000 & 0.001 & $-0.002 * *$ & -0.001 \\
\hline & $(0.001)$ & $(0.001)$ & $(0.001)$ & $(0.001)$ & $(0.001)$ & $(0.001)$ \\
\hline \multirow[t]{2}{*}{ Seats in district } & $-0.005 * *$ & $-0.005 * *$ & -0.002 & -0.003 & $-0.008 * * *$ & $-0.007 * *$ \\
\hline & $(0.002)$ & $(0.003)$ & $(0.004)$ & $(0.004)$ & $(0.003)$ & $(0.003)$ \\
\hline \multirow[t]{2}{*}{ Cabinet member } & $-0.029 *$ & $-0.031 * *$ & $-0.086 * * *$ & $-0.080 * *$ & -0.010 & -0.012 \\
\hline & $(0.015)$ & $(0.015)$ & $(0.031)$ & $(0.032)$ & $(0.019)$ & $(0.019)$ \\
\hline \multirow[t]{2}{*}{ Freshman } & $-0.117 * * *$ & $-0.114 * * *$ & $-0.079 *$ & $-0.083 *$ & $-0.144 * * *$ & $-0.142 * * *$ \\
\hline & $(0.020)$ & $(0.020)$ & $(0.046)$ & $(0.048)$ & $(0.025)$ & $(0.025)$ \\
\hline \multirow[t]{2}{*}{ Age $\geq 50$} & $-0.020 * *$ & $-0.019 *$ & 0.023 & 0.022 & $-0.043 * * *$ & $-0.042 * * *$ \\
\hline & $(0.010)$ & $(0.010)$ & $(0.019)$ & $(0.019)$ & $(0.014)$ & $(0.014)$ \\
\hline \multirow[t]{2}{*}{ Female } & 0.038 & 0.024 & -0.051 & -0.053 & $0.065 * *$ & 0.045 \\
\hline & $(0.024)$ & $(0.022)$ & $(0.033)$ & $(0.033)$ & $(0.033)$ & $(0.032)$ \\
\hline \multirow[t]{2}{*}{ School Abroad } & $-0.042 *$ & $-0.044^{*}$ & $-0.052 * *$ & $-0.053 * *$ & & \\
\hline & $(0.023)$ & $(0.023)$ & $(0.025)$ & $(0.025)$ & & \\
\hline \multirow[t]{2}{*}{$\mathrm{MA} / \mathrm{PhD}$} & -0.010 & -0.007 & & & & \\
\hline & $(0.012)$ & $(0.012)$ & & & & \\
\hline \multirow[t]{2}{*}{ Basic Sciences } & -0.028 & -0.028 & 0.011 & 0.003 & -0.022 & -0.023 \\
\hline & $(0.028)$ & $(0.028)$ & $(0.064)$ & $(0.061)$ & $(0.036)$ & $(0.035)$ \\
\hline \multirow[t]{2}{*}{ Comp Sci, Elect Eng } & 0.028 & 0.029 & 0.043 & 0.037 & 0.020 & 0.019 \\
\hline & $(0.031)$ & $(0.030)$ & $(0.075)$ & $(0.070)$ & $(0.038)$ & $(0.037)$ \\
\hline \multirow[t]{2}{*}{ Other Engineering } & -0.009 & -0.012 & -0.031 & -0.030 & 0.002 & -0.005 \\
\hline & $(0.018)$ & $(0.017)$ & $(0.053)$ & $(0.049)$ & $(0.021)$ & $(0.020)$ \\
\hline \multirow[t]{2}{*}{ Health Sciences } & 0.018 & 0.002 & 0.030 & 0.005 & 0.029 & 0.012 \\
\hline & $(0.020)$ & $(0.020)$ & $(0.052)$ & $(0.050)$ & $(0.026)$ & $(0.027)$ \\
\hline \multirow[t]{2}{*}{ Education } & 0.010 & 0.013 & -0.010 & -0.016 & 0.005 & 0.007 \\
\hline & $(0.022)$ & $(0.023)$ & $(0.072)$ & $(0.069)$ & $(0.027)$ & $(0.027)$ \\
\hline
\end{tabular}


Table 11 (concluded)

\begin{tabular}{lcccccc}
\hline & \multicolumn{2}{c}{ Whole Sample } & \multicolumn{2}{c}{ MPs with MA or PhD } & \multicolumn{2}{c}{ MPs without MA or PhD } \\
\hline & $(1)$ & $(2)$ & $(3)$ & $(4)$ & $(5)$ & $(6)$ \\
\hline Economics/Management & 0.009 & 0.011 & 0.047 & 0.045 & -0.001 & -0.000 \\
& $(0.017)$ & $(0.016)$ & $(0.050)$ & $(0.047)$ & $(0.020)$ & $(0.019)$ \\
Law & -0.021 & -0.019 & -0.024 & -0.034 & -0.024 & -0.021 \\
& $(0.018)$ & $(0.017)$ & $(0.068)$ & $(0.065)$ & $(0.020)$ & $(0.020)$ \\
Social Sciences & -0.005 & -0.001 & 0.036 & 0.028 & -0.019 & -0.009 \\
& $(0.020)$ & $(0.020)$ & $(0.052)$ & $(0.049)$ & $(0.028)$ & $(0.027)$ \\
Other & 0.008 & 0.015 & & & 0.041 & 0.058 \\
& $(0.029)$ & $(0.029)$ & & & $(0.037)$ & $(0.037)$ \\
\hline Observations & 2205 & 2088 & 440 & 415 & 1489 & 1408 \\
\hline
\end{tabular}

The outcome variable is Party Switch which takes the value of one if the MP's party affiliation at the beginning of the parliamentary term is different from their affiliation at the end of the term. Table presents the marginal effects obtained from probit regressions. The whole set of control variables are included in the regressions (as in Table 5). Robust standard errors clustered at the MP level are reported in parentheses. ${ }^{*},{ }^{* *}$, and $* * *$ indicate statistical significance at $10 \%, 5 \%$ and $1 \%$, respectively.

Basic Sciences - graduates who major in sciences such as chemistry, physics, biology, astronomy, geology. Comp Sci, Elect Eng - graduates who major in computer engineering, electric or electronics engineering, and mathematics, statistics Other Engineering - engineering in all other fields such as industrial engineering, civil engineering, mechanical engineering, chemical engineering, agricultural engineering, forestry engineering, and architecture. Health Sciences - dentistry, medical doctors, pharmaceutics, veterinarian. Education - teachers, foreign languages, Turkish language, physical education majors, graduates of fine arts schools and conservatories. Economics/Management - graduates from departments of economics, management, marketing, accounting, finance, banking, trade, tourism management and graduates of related schools. Law - graduates of law school. Social Sciences - graduates from departments of geography, history, sociology, philosophy, and other social sciences, theology, political science, international relations, public administration, journalism. Other - graduates with other majors, undeclared/unknown majors, and graduates of military schools and police academy. 
Table 12

The Effect of Party Switching on Ex-ante Re-election Chances in the Next Election

\begin{tabular}{|c|c|c|c|c|c|}
\hline & $(1)$ & (2) & (3) & (4) & (5) \\
\hline & $\begin{array}{l}\text { Whole } \\
\text { Sample }\end{array}$ & \multicolumn{4}{|c|}{ Conditional on running in the next election } \\
\hline & $\begin{array}{c}\text { Ran for } \\
\text { re- } \\
\text { election }\end{array}$ & $\begin{array}{l}\text { Min } \% \text { vote } \\
\text { for guaranteed } \\
\text { re-election }\end{array}$ & $\begin{array}{l}\text { Min \% vote } \\
\text { for guaranteed } \\
\text { re-election }\end{array}$ & $\begin{array}{l}\text { Min \% vote for } \\
\text { re-election } \\
\text { prob }>0\end{array}$ & $\begin{array}{l}\text { Min } \% \text { vote } \\
\text { for re-election } \\
\text { prob }>0\end{array}$ \\
\hline Party Switch & $\begin{array}{l}-0.047 \\
(0.036)\end{array}$ & $\begin{array}{c}-4.170^{* * *} \\
(1.085)\end{array}$ & $\begin{array}{c}-4.951 * * * \\
(1.128)\end{array}$ & $\begin{array}{c}-1.741 * * * \\
(0.528)\end{array}$ & $\begin{array}{c}-1.964 * * * \\
(0.540)\end{array}$ \\
\hline $\begin{array}{l}\text { Min } \% \text { vote for } \\
\text { guaranteed election }\end{array}$ & & & $\begin{array}{c}0.358 * * * \\
(0.042)\end{array}$ & & \\
\hline $\begin{array}{l}\text { Min } \% \text { vote for } \\
\text { election prob }>0\end{array}$ & & & & & $\begin{array}{c}0.293 * * * \\
(0.043)\end{array}$ \\
\hline $\begin{array}{l}\text { Member of the } \\
\text { governmentl party }\end{array}$ & $\begin{array}{c}-0.096^{* *} \\
(0.040)\end{array}$ & $\begin{array}{l}-1.346 \\
(1.281)\end{array}$ & $\begin{array}{l}-1.723 \\
(1.272)\end{array}$ & $\begin{array}{l}-0.172 \\
(0.529)\end{array}$ & $\begin{array}{l}-0.300 \\
(0.534)\end{array}$ \\
\hline $\begin{array}{l}\text { Elected from same } \\
\text { party before }\end{array}$ & $\begin{array}{l}-0.068 \\
(0.049)\end{array}$ & $\begin{array}{c}1.129 \\
(1.619)\end{array}$ & $\begin{array}{c}1.244 \\
(1.458)\end{array}$ & $\begin{array}{c}0.450 \\
(0.742)\end{array}$ & $\begin{array}{c}0.476 \\
(0.668)\end{array}$ \\
\hline Relative Salary & $\begin{array}{l}-0.029 \\
(0.037)\end{array}$ & $\begin{array}{l}-1.870 \\
(1.250)\end{array}$ & $\begin{array}{l}-0.987 \\
(1.217)\end{array}$ & $\begin{array}{c}-1.100 * * \\
(0.521)\end{array}$ & $\begin{array}{l}-0.713 \\
(0.507)\end{array}$ \\
\hline Party's Vote Share & $\begin{array}{l}0.002 * \\
(0.001)\end{array}$ & $\begin{array}{c}0.295^{* * *} \\
(0.046)\end{array}$ & $\begin{array}{c}0.145^{* * * *} \\
(0.046)\end{array}$ & $\begin{array}{c}0.115^{* * * *} \\
(0.019)\end{array}$ & $\begin{array}{c}0.066^{* * * *} \\
(0.019)\end{array}$ \\
\hline Seats in district & $\begin{array}{c}0.013^{* *} \\
(0.005)\end{array}$ & $\begin{array}{l}-0.219 \\
(0.169)\end{array}$ & $\begin{array}{l}-0.138 \\
(0.166)\end{array}$ & $\begin{array}{c}0.043 \\
(0.091)\end{array}$ & $\begin{array}{l}-0.085 \\
(0.091)\end{array}$ \\
\hline Cabinet member & $\begin{array}{c}0.188 * * * \\
(0.038)\end{array}$ & $\begin{array}{c}-10.280^{* * * *} \\
(0.959)\end{array}$ & $\begin{array}{c}-7.407 * * * \\
(0.902)\end{array}$ & $\begin{array}{c}-4.688^{* * *} \\
(0.421)\end{array}$ & $\begin{array}{c}-3.579 * * * \\
(0.400)\end{array}$ \\
\hline Freshman & $\begin{array}{l}-0.091^{*} \\
(0.048)\end{array}$ & $\begin{array}{c}5.480 * * * \\
(1.643)\end{array}$ & $\begin{array}{l}3.206^{* *} \\
(1.501)\end{array}$ & $\begin{array}{c}2.343 * * * \\
(0.771)\end{array}$ & $\begin{array}{l}1.388^{*} \\
(0.713)\end{array}$ \\
\hline Age $\geq 50$ & $\begin{array}{c}-0.133^{* * *} \\
(0.022)\end{array}$ & $\begin{array}{l}-0.786 \\
(0.980)\end{array}$ & $\begin{array}{l}-0.300 \\
(0.885)\end{array}$ & $\begin{array}{l}-0.041 \\
(0.440)\end{array}$ & $\begin{array}{c}0.107 \\
(0.405)\end{array}$ \\
\hline Female & $\begin{array}{c}0.062 \\
(0.051)\end{array}$ & $\begin{array}{l}-1.925 \\
(1.866)\end{array}$ & $\begin{array}{l}-2.872^{*} \\
(1.635)\end{array}$ & $\begin{array}{l}-1.078 \\
(0.920)\end{array}$ & $\begin{array}{l}-1.460^{*} \\
(0.820)\end{array}$ \\
\hline School Abroad & $\begin{array}{c}0.022 \\
(0.042)\end{array}$ & $\begin{array}{c}-3.665^{* *} \\
(1.631)\end{array}$ & $\begin{array}{l}-2.423 \\
(1.492)\end{array}$ & $\begin{array}{c}-1.638^{* *} \\
(0.718)\end{array}$ & $\begin{array}{l}-1.036 \\
(0.672)\end{array}$ \\
\hline $\mathrm{MA} / \mathrm{PhD}$ & $\begin{array}{c}0.040 \\
(0.025)\end{array}$ & $\begin{array}{c}-2.438^{* *} \\
(1.086)\end{array}$ & $\begin{array}{l}-1.577 \\
(0.976)\end{array}$ & $\begin{array}{c}-1.133^{* *} \\
(0.482)\end{array}$ & $\begin{array}{c}-0.877 * * \\
(0.433)\end{array}$ \\
\hline Observations & 2416 & 1632 & 1632 & 1632 & 1632 \\
\hline
\end{tabular}

The outcome variable in column 1 is an indicator for whether the MP ran for a seat in the parliament in the subsequent election. The outcome variables in columns 2 and 3 (4 and 5) are the threshold vote share for guaranteed election (threshold for non-zero re-election probability) in the subsequent election. Column 1 presents marginal effects obtained from probit estimated over the whole sample. Columns 2 to 5 are estimated with OLS over the sample of MPs who ran for re-election. Inverse of the predicted probabilities of running for re-election are used as weights (inverse probability weights) in regression 2 to 5 . The whole set of control variables are included in the regressions (as in Table 5). Robust standard errors clustered at the MP level are reported in parentheses. $* * *$, and $* * *$ indicate statistical significance at $10 \%, 5 \%$ and $1 \%$, respectively. 
Table 13

Effect of Party Switching on the Probability of Re-Election

\begin{tabular}{|c|c|c|c|c|}
\hline & (1) & (2) & (3) & (4) \\
\hline & $\begin{array}{c}>10 \% \\
\text { Threshold }\end{array}$ & Re-elected & Re-elected & Re-elected \\
\hline Party Switch & $\begin{array}{c}-0.166^{* * *} \\
(0.021)\end{array}$ & $\begin{array}{c}0.002 \\
(0.001)\end{array}$ & $\begin{array}{c}0.002 \\
(0.001)\end{array}$ & $\begin{array}{c}0.004 * * * \\
(0.001)\end{array}$ \\
\hline $\begin{array}{l}\text { Min } \% \text { vote for } \\
\text { guaranteed election }\end{array}$ & & $\begin{array}{c}-0.000 * * * \\
(0.000)\end{array}$ & & \\
\hline $\begin{array}{l}\text { Min } \% \text { vote for } \\
\text { election prob }>0\end{array}$ & & & $\begin{array}{c}-0.001 * * * \\
(0.000)\end{array}$ & \\
\hline $\begin{array}{l}\text { Member of the } \\
\text { governmental party }\end{array}$ & $\begin{array}{c}0.041 \\
(0.025)\end{array}$ & $\begin{array}{l}-0.002 \\
(0.001)\end{array}$ & $\begin{array}{l}-0.002 \\
(0.001)\end{array}$ & $\begin{array}{l}-0.002 \\
(0.001)\end{array}$ \\
\hline $\begin{array}{l}\text { Elected from same } \\
\text { party before }\end{array}$ & $\begin{array}{c}0.019 \\
(0.027)\end{array}$ & $\begin{array}{l}-0.002 \\
(0.002)\end{array}$ & $\begin{array}{l}-0.002 \\
(0.002)\end{array}$ & $\begin{array}{l}-0.001 \\
(0.002)\end{array}$ \\
\hline Relative Salary & $\begin{array}{l}-0.005 \\
(0.008)\end{array}$ & $\begin{array}{c}0.005 * * * \\
(0.001)\end{array}$ & $\begin{array}{c}0.005 * * * \\
(0.001)\end{array}$ & $\begin{array}{c}0.006^{* * *} \\
(0.001)\end{array}$ \\
\hline Party’s Vote Share & $\begin{array}{l}-0.001 * \\
(0.001)\end{array}$ & $\begin{array}{c}0.000 \\
(0.000)\end{array}$ & $\begin{array}{c}0.000 \\
(0.000)\end{array}$ & $\begin{array}{l}-0.000 \\
(0.000)\end{array}$ \\
\hline Seats in district & $\begin{array}{l}-0.001 \\
(0.001)\end{array}$ & $\begin{array}{c}-0.000 * * \\
(0.000)\end{array}$ & $\begin{array}{l}-0.000 \\
(0.000)\end{array}$ & $\begin{array}{l}-0.000 \\
(0.000)\end{array}$ \\
\hline Cabinet member & $\begin{array}{l}0.053 * * * \\
(0.015)\end{array}$ & $\begin{array}{l}0.003 * * \\
(0.001)\end{array}$ & $\begin{array}{l}0.003 * * \\
(0.001)\end{array}$ & $\begin{array}{c}0.005^{* * *} \\
(0.001)\end{array}$ \\
\hline Freshman & $\begin{array}{c}0.017 \\
(0.025)\end{array}$ & $\begin{array}{l}-0.002 \\
(0.002)\end{array}$ & $\begin{array}{l}-0.002 \\
(0.002)\end{array}$ & $\begin{array}{l}-0.002 \\
(0.002)\end{array}$ \\
\hline Age $\geq 50$ & $\begin{array}{l}-0.025 * \\
(0.013)\end{array}$ & $\begin{array}{l}-0.002 \\
(0.001)\end{array}$ & $\begin{array}{c}-0.002 * \\
(0.001)\end{array}$ & $\begin{array}{l}-0.002 \\
(0.001)\end{array}$ \\
\hline Female & $\begin{array}{l}-0.002 \\
(0.021)\end{array}$ & $\begin{array}{c}-0.001 \\
(0.002)\end{array}$ & $\begin{array}{l}-0.002 \\
(0.002)\end{array}$ & $\begin{array}{c}-0.001 \\
(0.002)\end{array}$ \\
\hline School Abroad & $\begin{array}{l}0.044 * \\
(0.023)\end{array}$ & $\begin{array}{c}0.005 * * \\
(0.002)\end{array}$ & $\begin{array}{c}0.005 * * \\
(0.002)\end{array}$ & $\begin{array}{c}0.006^{* * *} \\
(0.002)\end{array}$ \\
\hline $\mathrm{MA} / \mathrm{PhD}$ & $\begin{array}{l}-0.020 \\
(0.013)\end{array}$ & $\begin{array}{c}0.000 \\
(0.001)\end{array}$ & $\begin{array}{c}0.001 \\
(0.001)\end{array}$ & $\begin{array}{c}0.001 \\
(0.001)\end{array}$ \\
\hline Observations & 1632 & 1630 & 1630 & 1630 \\
\hline
\end{tabular}

Notes: The outcome variable in column 1 is an indicator for whether the MP's party has passed the $10 \%$ national election threshold in the subsequent election. The outcome variable in columns 2 to 4 is an indicator for whether the MP is re-elected in the subsequent election. Table presents marginal effects obtained from probit regressions over the sample of MPs who ran for re-election. Inverse of the predicted probabilities of passing the $10 \%$ threshold are used as weights (inverse probability weights) in regressions 2 to 4 . The variable of interest, Party Switch, takes the value of one if the MP's party affiliation at the beginning of the parliamentary term is different from their affiliation at the end of the term. The whole set of control variables are included in the regressions (as in Table 5). Robust standard errors clustered at the MP level are reported in parentheses. *, **, and *** indicate statistical significance at $10 \%, 5 \%$ and $1 \%$, respectively. 


\section{Table 14}

The Change in the Proportion of Votes Received by Parties (in Consecutive Elections)

\begin{tabular}{lccc}
\hline & $(1)$ & $(2)$ & $(3)$ \\
\hline MPs Gained $_{\mathrm{t}}$ & $1.718^{* *}$ & $1.846^{* *}$ & $2.073^{* *}$ \\
& $(0.698)$ & $(0.728)$ & $(0.950)$ \\
$\Delta$ National Vote Share $_{\mathrm{t}}$ & $0.827^{* * *}$ & $0.828^{* * *}$ & $0.832^{* * *}$ \\
& $(0.024)$ & $(0.024)$ & $(0.024)$ \\
$\Delta$ Government $_{\mathrm{t}}$ & $-0.563 * *$ & $-0.564^{* *}$ & $-0.592^{* *}$ \\
& $(0.233)$ & $(0.235)$ & $(0.230)$ \\
\hline Observations $^{\text {Term FE }}$ & 3377 & 3377 & 3377 \\
Party FE & Yes & Yes & Yes \\
City FE & Yes & Yes & \\
Party $\times$ City FE & & Yes & \\
\hline
\end{tabular}

Notes: Dependent variable is the change in party's city-wide vote share (\%) from the previous election.

MPs Gained $_{t}$ is the number of MPs representing city $c$ switched to party $p$ in the parliamentary term prior to the elections. $\Delta$ National Vote Share is the change in the national vote share of party $p$ in elections at $t$ from their national vote share in the previous elections at $t-1$. $\Delta$ Government $_{t}$ is the change in an indicator that takes the value of if party $p$ was part of the government at the day of elections. Robust standard errors clustered at the city level are reported in parentheses. $*, * *$, and $* * *$ indicate statistical significance at $10 \%, 5 \%$ and $1 \%$, respectively. 
Table 15

The Relationship between Party Switching and Ideological Change

\begin{tabular}{|c|c|c|}
\hline & $(1)$ & (2) \\
\hline & \multicolumn{2}{|c|}{$\begin{array}{c}\text { Ideology } \\
\text { (End-of-term) }\end{array}$} \\
\hline Party Switch & $\begin{array}{l}3.964 * * * \\
(0.485)\end{array}$ & $\begin{array}{c}4.030 * * * \\
(0.468)\end{array}$ \\
\hline $\begin{array}{l}\text { Ideology } \\
\text { (Beginning-of-term) }\end{array}$ & $\begin{array}{c}1.012 * * * \\
(0.001)\end{array}$ & $\begin{array}{c}1.015 * * * \\
(0.004)\end{array}$ \\
\hline Party Switch×Ideology & $\begin{array}{c}-0.634 * * * \\
(0.075)\end{array}$ & $\begin{array}{c}-0.642 * * * \\
(0.073)\end{array}$ \\
\hline Member of Gov't Party & & $\begin{array}{c}-0.074 * * * \\
(0.028)\end{array}$ \\
\hline $\begin{array}{l}\text { Elected from same } \\
\text { party before }\end{array}$ & & $\begin{array}{c}0.103 \\
(0.077)\end{array}$ \\
\hline Relative salary & & $\begin{array}{l}-0.053 \\
(0.040)\end{array}$ \\
\hline Party's Vote Share & & $\begin{array}{l}-0.001 \\
(0.001)\end{array}$ \\
\hline Seats in district & & $\begin{array}{l}-0.000 \\
(0.005)\end{array}$ \\
\hline Cabinet member & & $\begin{array}{l}-0.028 \\
(0.034)\end{array}$ \\
\hline Freshman & & $\begin{array}{l}0.132^{*} \\
(0.077)\end{array}$ \\
\hline Age $\geq 50$ & & $\begin{array}{c}0.006 \\
(0.021)\end{array}$ \\
\hline Female & & $\begin{array}{l}-0.031 \\
(0.056)\end{array}$ \\
\hline School Abroad & & $\begin{array}{l}-0.017 \\
(0.034)\end{array}$ \\
\hline $\mathrm{MA} / \mathrm{PhD}$ & & $\begin{array}{l}-0.002 \\
(0.023)\end{array}$ \\
\hline Observations & 2,369 & 2,358 \\
\hline
\end{tabular}

The outcome variable is the Political Scale Index (PSI) of the MP's party as of the end of the term. PSI measures the positioning of the MP's party in a political spectrum ranging between 1 (most left) to 10 (most right). Table presents OLS estimates. The whole set of control variables are included in the regressions (as in Table 5) except indicators for MP's beginning of the term party. Robust standard errors clustered at the MP level are reported in parentheses. *, $* *$, and $* * *$ indicate statistical significance at $10 \%, 5 \%$ and $1 \%$, respectively. 


\section{References}

Acemoglu, D., J. Robinson, and R. Tovrik. 2013. "Why Do Voters Dismantle Checks and Balances?" Review of Economic Studies 80, 854-875.

Akhmedov, A., and E. Zhuravskaya. 2004. "Opportunistic Political Cycles: Test in a Young Democracy Setting.” The Quarterly Journal of Economics 119 (4), pp. 1301-1338.

Alesina, A., U. Troiano, and T. Cassidy. 2015. "Old and Young Politicians.” NBER Working Paper No. 20977.

Alesina, A., N. Roubini, and G. Cohen. 1997. Political Cycles and the Macroeconomy Cambridge, MA: MIT Press.

Altonji, J., T. Elder, and C. Taber. 2005. "Selection on Observed and Unobserved Variables: Assessing the Effectiveness of Catholic Schools," Journal of Political Economy 113(1), pp. 151-184.

Ashworth, S. 2005. "Reputational Dynamics and Political Careers." Journal of Law, Economics and Organization 21(2), pp. 441-466.

Barro, R. 1973. "The Control of Politicians." Public Choice 14(1), pp. 19-42.

Becker, G., and G. Stigler. 1974. "Law Enforcement, Malfeasance, and Compensation of Enforcers.” The Journal of Legal Studies 3(1), pp. 1-18.

Besley, T., J. Montalvo, and M. Reynal-Querol. 2011. “Do Educated Leaders Matter?” Economic Journal 121, pp. 205-227.

Besley, T. 2006. Principled Agents?: The Political Economy of Good Government, New York: Oxford University Press.

Besley, T. 2004. "Paying Politicians: Theory and Evidence." Journal of the European Economic Association 2(2-3), pp. 193-215.

Bhavnani, R. 2012. 'Using Asset Disclosures to Study Politicians' Rents: An Application to India." Working Paper presented at Annual Bank Conferences on Development Economics, Washington, DC. 
Brender, A., and A. Drazen. 2008. "How Do Budget Deficits and Economic Growth Affect Reelection Prospects? Evidence from a Large Panel of Countries." American Economic Review 98(5), pp. 2203-2220.

Brender, A., and A. Drazen. 2005. "Political Budget Cycles in new versus established democracies.” Journal of Monetary Economics 52, pp. 1271-1295.

Calonico, S., M.D. Cattaneo and R. Titiunik. 2014. "Robust Nonparametric Confidence Intervals for Regression-Discontinuity Designs.” Econometrica 82(6), pp. 2295-2326.

Carkoglu, A., and M. Hinich. 2006. “A Spatial Analysis of Turkish Party Preferences.” Electoral Studies 25(2), pp. 369-392.

Caselli, F., and M. Morelli. 2004. "Bad Politicians." Journal of Public Economics 88(3-4), pp. 759-782.

Croson, R., and U. Gneezy. 2009. "Gender Differences in Preferences.” Journal of Economic Literature 47(2), pp. 448-474.

Dal Bó, E., P. Dal Bó, and J. Snyder. 2009. "Political Dynasties." Review of Economic Studies 76, pp. 115-142.

Da Silveira, B. and J. Mello. 2011. "Campaign Advertising and Election Outcomes: Quasinatural Experiment Evidence from Gubernatorial Elections in Brazil." Review of Economic Studies 78(2), pp. 590- 612.

Diermeier, D., M. Keane, and A. Merlo. 2005. "A Political Economy Model of Congressional Careers." American Economic Review 95(1), pp. 347-373.

Desposato , S.W. 2006. "Parties for Rent? Ambition, Ideology, and Party Switching in Brazil's Chamber of Deputies.” American Journal of Political Science 50(1), pp.62-80.

Drazen, A., and M. Eslava. 2010. "Electoral Manipulation via Voter-Friendly Spending: Theory and Evidence." Journal of Development Economics 92, pp. 39-52.

Eggers, A., and J. Hainmueller. 2009. "MPs for Sale? Returns to Office in Postwar British Politics.” American Political Science Review 103(4), pp. 513-533.

Fair, R. 1978. "The Effect of Economic Events on Votes for President." The Review of Economics and Statistics 60(2), pp. 159-173.. 
Fearon, J. 1999. "Electoral Accountability and the control of politicians: selecting good types versus sanctioning poor performance" i n Democracy, Accountability and Representation, eds: A. Przeworski, S. Stokes, and B. Manin, New York: Cambridge University Press, pp. 55-97.

Ferejohn, J. 1986. "Incumbent Performance and Electoral Control." Public Choice 50(2), pp. 525.

Ferraz, C., and F. Finan. 2008. "Exposing Corrupt Politicians: The Effect of Brazil's Publicly Released Audits on Electoral Outcomes." Quarterly Journal of Economics123(2), pp. 703745 .

Finan, F., and L. Schechter. 2012. "Vote-buying and Reciprocity." Econometrica 80(2), pp. 863882.

Fisman, R., F. Schulz, and V. Vig. 2014. "The Private Returns to Public Office." Journal of Political Economy 122(4), pp. 806-862.

Gagliarducci, S., and T. Nannicini. 2013. "Do Better Paid Politicians Perform Better? Disentangling Incentives from Selection." Journal of the European Economic Association 11(2), pp. 369-398.

Gagliarducci, S., and D. Paserman. 2012. "Gender Interactions within Hierarchies: Evidence from the Political Arena." Review of Economic Studies 79, 1021-1052.

Galasso, V., and T. Nannicini. 2014. "So Closed: Political Selection in Proportional Systems" Bocconi University Working Papers, no. 526.

Heller, W.B., and C. Mershon. 2009a. "Introduction: Legislative Party Switching, Parties and Party Systems" Chapter 1 in Political Parties and Legislative Party Switching, Eds. W.B. Heller, and C. Mershon, New York, NY: Palgrave MacMillan.

Imbens, G.W. and T. Lemieux. 2008. "Regression discontinuity designs: A guide to practice." Journal of Econometrics 142(2), pp. 615-635.

Imbens, G. and K. Kalyanaraman. 2012. "Optimal Bandwidth Choice for the Regression Discontinuity Estimator.” The Review of Economic Studies 79(3), pp.933-959.

Jacob, B., and L. Lefgren. 2003. "Are Idle Hands the Devil's Workshop? Incapacitation, Concentration, and Juvenile Crime.” American Economic Review 93(5), pp. 1560-1577. 
Keane, M.P. and A. Merlo. 2010. "Money, Political Ambition, and the Career Decisions of Politicians.” American Economic Journal: Microeconomics 2(3), pp.186-215.

Khemani, S. 2004. "Political cycles in a developing economy: effect of elections in the Indian States." Journal of Development Economics 73(1), pp. 125-154.

Lewis-Beck, M., R. Nadeau, and A. Elias. 2008. "Economics, Party, and the Vote: Causality Issues and Panel Data" American Journal of Political Science 52(1), pp. 84-95.

Malley, J., A. Philippopoulos, and U. Woitek. 2007 "Electoral uncertainty, fiscal policy and macroeconomic fluctuations." Journal of Economic Dynamics and Control 31, pp. 10511080.

Markus, G. 1988. "The Impact of Personal and National Economic Conditions on the Presidential Vote: A Pooled Cross-Sectional Analysis.” American Journal of Political Science 32, pp. 137-154.

McCrary, J. 2008. "Manipulation of the Running Variable in the Regression Discontinuity Design: A Density Test.” Journal of Econometrics 142(2), pp.698-714.

Mocan, N., and D. Altindag. 2013. "Salaries and Work Effort: An Analysis of the European Union Parliamentarians.” Economic Journal 123(573), pp.145-57.

Mocan, N., and D. Rees. 2005. "Economic Conditions, Deterrence and Juvenile Crime: Evidence from Micro Data." American Law and Economics Review 7(2), pp. 319-349

Nordhaus, W., A. Alesina, and C. Schultze. 1989. "Alternative Approaches to the Political Business Cycles.” Brookings Papers on Economic Activity (1989) 2, pp. 1-68.

O'Brien, D. Z., and Y. Shomer. 2013 “A Cross-National Analysis of Party Switching." Legislative Studies Quarterly 38(1), pp. 111-41.

Oster, E. 2014. "Unobservable Selection and Coefficient Stability: Theory and Evidence" Working Paper, available at $<$ http://www.brown.edu/research/projects/oster/sites/brown.edu.research.projects.oster/files/ uploads/Unobservable_Selection_and_Coefficient_Stability.pdf.

Palomares, A., and V. Ramirez. 2003. "Thresholds of the Divisor Methods." Numerical Algorithms 34(2-4), pp.405-15. 
Persson, T., G. Roland, and G. Tabellini. 1997. "Separation of Powers and Political Accountability.” Quarterly Journal of Economics 112(4), pp. 1163-1202.

Rogoff, K. 1990. “Equilibrium Political Budget Cycles.” American Economic Review 80, pp. 2136.

Secor, A. 2001 "Ideologies in Crisis: Political Cleavages and Electoral Politics in Turkey in the 1990s." Political Geography (20), pp. 539-560.

Shi, M., and J. Svensson. 2006. "Political Budget Cycles: Do They Differ Across Countries and Why?” Journal of Public Economics 90, pp. 1367-1389.

Wooldridge, J. 2002. "Inverse Probability Weighted M-estimators for Sample Selection, Attrition, and Stratification.” Portuguese Economic Journal 1(2), pp. 117-139. 